\title{
The Life Cycle of Toxoplasma gondii in the Natural Environment
}

\author{
Emmanuelle Gilot-Fromont, Maud Lélu, Marie-Laure Dardé, \\ Céline Richomme, Dominique Aubert, Eve Afonso, \\ Aurélien Mercier, Cécile Gotteland and Isabelle Villena
}

Additional information is available at the end of the chapter

http://dx.doi.org/10.5772/48233

\section{Introduction}

Toxoplasma gondii (T. gondii) is considered as one of the most successful parasites in the world. This success is first illustrated by its worldwide distribution, from arctic to hot desert areas, including isolated islands and in cities [1]. T. gondii is also among the most prevalent parasites in the global human population, with around one third of the population being infected [2]. Finally, it is able to infect, or be present in, the highest number of host species: any warm-blooded animal may act as an intermediate host, and oocysts may be transported by invertebrates such as filtrating mussels and oysters [1,3].

Beyond this ubiquitous distribution lies a fascinating transmission pattern: simply saying that $T$. gondii has a complex life cycle does not encompass all transmission routes and modes that can be used by the parasite to pass from definitive hosts (DHs), where sexual reproduction occurs, to intermediate hosts (IHs). The "classical" complex life cycle uses felids (domestic and wild-living cats) as DHs and their prey as IHs (Figure 1). Felids are infected by eating infected prey and host the sexual multiplication of the parasite. They excrete millions of oocysts that sporulate in the environment. Sporulated oocysts may survive during several years and may disperse through water movements, soil movements and microfauna. Ingesting a single sporulated oocyst may be sufficient to infect an $\mathrm{IH}$ and begin the asexual reproduction phase [1]. This classical life cycle thus relies on a preypredator relationship and on environmental contamination, like other parasites, e.g., Echinococcus multilocularis [4].

However, beside this classical cycle, T. gondii shows specific abilities that allow it to use "complementary" transmission routes (Figure 1). During the phase of asexual multiplication, tachyzoites may disseminate to virtually any organ within the $\mathrm{IH}$, in 
particular to muscles, brain, placenta, udder and gonads. Asexual forms are then infectious to new hosts, thus direct infection among $\mathrm{IH}$ is possible by several routes which epidemiological importance has to be discussed: vertical transmission through the placenta, pseudo-vertical transmission through the milk, and sexual transmission through the sperm $[1,5,6]$. In humans, T. gondii may also be transmitted during blood or organ transplant. Finally, the infectivity of asexual forms towards new IHs entails the ability for the parasite to be transmitted among IHs by carnivory. This transmission route is estimated to cause the majority of cases in humans [7], although people may also get contaminated by ingesting oocysts after a contact with contaminated soil, water, vegetables or cat litter. All the possible transmission routes among IH make the parasite able to maintain its life cycle, at least during a few generations, in the absence of $\mathrm{DH}$ and without environmental stage [8]. Moreover, at a high dose, oocysts from the environment may also be infectious for DHs [9], thus the parasite may bypass the IH and use a DHs-environment cycle. The infectivity of oocysts towards cats is relatively low thus the importance of this cycle may be questioned [10]. However, taken together, these observations suggest that T. gondii may theoretically have two distinct life cycles, one among IHs and the other one between DHs and environment.

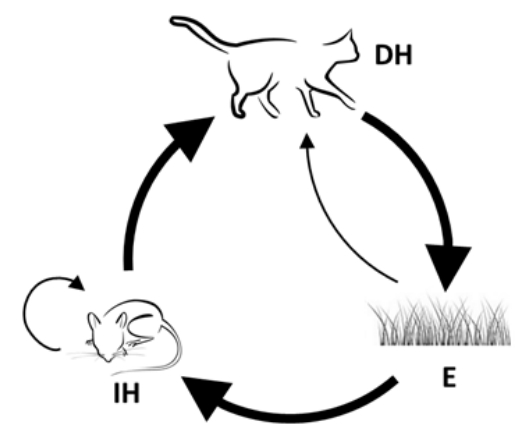

Figure 1. Life cycle of Toxoplasma gondii: the "classical" life cycle between intermediate hosts (IH, rodents), definitive hosts ( $\mathrm{DH}$, felids) and environment (E, soil) is represented with large arrows, while the "complementary" transmission routes (vertical or horizontal transmission among IHs and environment-to-cat transmission) are represented with small arrows.

Moreover, in IHs, the infection of the brain results in several specific clinical manifestations, modifications of host behaviour and life history that influence transmission. As a result of its presence in the brain of IHs, T. gondii manipulates host behaviour in two ways, by specifically increasing attractiveness of cat odours to rodent IHs, thus favouring transmission from $\mathrm{IH}$ to $\mathrm{DH}[5,11]$, and by increasing the sexual attractiveness of infected males, which favours sexual transmission [6].

These numerous capacities of transmission clearly allow T. gondii to be distributed worldwide. However, this does not mean that the risk of toxoplasmosis is identical everywhere. On the contrary, a highly structured pattern of infection can be demonstrated, for example by comparing the level of infection of different human populations. Among 
countries, nationwide seroprevalences in women of childbearing age vary from less than $10 \%$ to more than $60 \%$ [12]. Within countries, a strong variability is also present: in France, the incidence of T. gondii varies from 1 to 68 cases per 1000 pregnancies among the 22 metropolitan regions [13]. Finally, spatial heterogeneity is also present at a more local scale, for example among districts within a region, and up to the level of families: within a village, individuals of the same family tended to have identical serological status [14]. Due to this heterogeneous distribution, the burden of toxoplasmosis and the associated socio-economic cost are unevenly distributed. Elucidating the causes of this distribution of T. gondii is necessary to improve prevention. However, this proves to be a difficult task, as the variability of parasite prevalence may reflect variations in many aspects of the life cycle. For example, considering the "classical" cat-environment-prey life cycle, the transmission from $\mathrm{IH}$ to $\mathrm{DH}$ likely depends on the level of predation of DHs on IHs, thus on the presence and densities of DHs and IHs, as well as on the diet of DHs. The survival of oocysts is influenced by temperature, moisture and UV radiation, thus should be determined by the meteorological conditions prevailing in the area, while dispersal depends on soil and water movements, as well as on the accumulation in invertebrates. The complementary routes of infection depend on the presence of omnivorous species (carnivory), the population dynamics of $\mathrm{IH}$ populations (vertical transmission) and the social structure (sexual and milk transmission).

In this chapter we aim to provide a comprehensive overview of factors that are recognized or can be expected to determine T. gondii dynamics in animal populations and in the environment, which constitute the reservoir of human infection, i.e., a set of epidemiologically connected populations and environments in which the pathogen can be permanently maintained and from which infection is transmitted to the defined target population [15]. Although the risk for people is largely due to the quality and intensity of their contacts with this reservoir, here we only deal with variations of the cycle in the environment and in animals. We summarize which mechanisms are now established and identify areas where data are lacking. We first show that the dynamics of the life cycle varies according to the relative densities of IHs and DHs, in particular along the urban-rural-wild gradient. Then we detail the variations observed in each of these environments at different spatial scales, and the factors that have been found to influence transmission dynamics. We conclude on how the variations described here should affect human exposure and should be considered for prevention.

\section{The urban- rural-wild gradient}

The life cycle of T. gondii is dependent on populations of IHs and DHs, and on the level of predation between them. These ecological determinants are themselves dependent on their environment. Because humans exert a major influence on the structure of their environment, the first structuration of these IH-DH communities comes from the urbanization gradient. We first explicit how IHs and DHs populations vary along this gradient before detailing how these variations affect the dynamics of $T$. gondii. 


\subsection{Host densities and predation rates vary along a urbanization gradient}

Taking advantage of a high adaptability and following human migrations, the domestic cat Felis catus has colonized a wide variety of habitats, ranging from urban areas to nonanthropized islands, through, agricultural areas, arid or semi-arid areas, villages or cities, from polar to equatorial climatic regions [16]. However, due to the behavioural plasticity of this species, population density and structure vary, depending on the abundance and distribution of food resources and shelters [16, 17]. In particular, cat populations are structured differently along an urban-rural-non-anthropized ("wild") gradient (Figure 2). The highest densities of cats are found in urban populations of stray cats locally more than 1000 cats/ $\mathrm{km}^{2}[18,19]$. At these high densities, cats form large multimale-multifemale social groups and share their territory, as well as available resources [16]. Most resources are provided directly or not, by people (feeders, garbage) [19]. In rural areas, population density is moderate (100-300 cats/ $\left.\mathrm{km}^{2}\right)$ [20, 21, 22]. Most cats have an owner who provides food and shelter but cats are generally free to roam [23]. An important part of cats diet result from predation: 15 to $90 \%$ depending on cat lifestyle [24, 16]. In rural areas, the spatial distribution of cats is based on human settlements: the social groups are based on a house or farm that provides most of the feeding and nesting resources. Around a feeding point, cats may form groups of up to 20 individuals, often constituted by related females and their kittens [16]. In fact, in such areas, a gradient can be observed between pet-owned cats mostly fed by the owner, to farm cats and feral cats mostly living on predation. Finally, feral cats occupying non-anthropized areas (sub-Antarctic, arid or forested areas), survive exclusively through predation, live at low density (1 to $\left.10 \mathrm{cats} / \mathrm{km}^{2}\right)$, in large and nonoverlapping home ranges $[25,26]$.

Rodent densities also vary along the urban-rural-wild gradient (Figure 2). However, comparisons are not straightforward since many species are concerned and most of them are not present in all environments. The available estimates suggest that some species may live at very high densities in agricultural landscapes: for example, common voles Microtus arvalis and water voles Arvicola terrestris may reach 100000 individuals $/ \mathrm{km}^{2}$ [27]. In contrast, in urban areas, the density of wood mice Apodemus sylvaticus was estimated to lie around 2000 - $8000 \mathrm{mice} / \mathrm{km}^{2}[28,29]$.

The third parameter that varies along the urban-rural-wild gradient is the rate of predation of rodents by cats, i.e., how many rodents does a cat ingest per unit of time. This parameter is crucial for the transmission of $T$. gondii from $\mathrm{IH}$ to $\mathrm{DH}$ : combined with the prevalence in prey, it determines the risk for a cat to get infected. The importance of the predation rate is illustrated by the finding that cats with frequent outdoor access show higher predation rates [16] and higher prevalences than cats not allowed to roam [30, 31, 32, 33, 34]. The predation rate depends on the availability of rodents, i.e., on the density of rodents relative to cats, and on the availability of other food resources provided by people. The predation rate is lowest in urban populations, ranging from 10 to 27 prey/cat/year [35, 36, 37]. For suburban and rural sites, estimated values for predation rates range from 21 to 436 prey/cat/year [10, 24, $38,39]$. Finally, the predation rate should be highest in non-anthropized areas, where cat exclusively live on predation. 


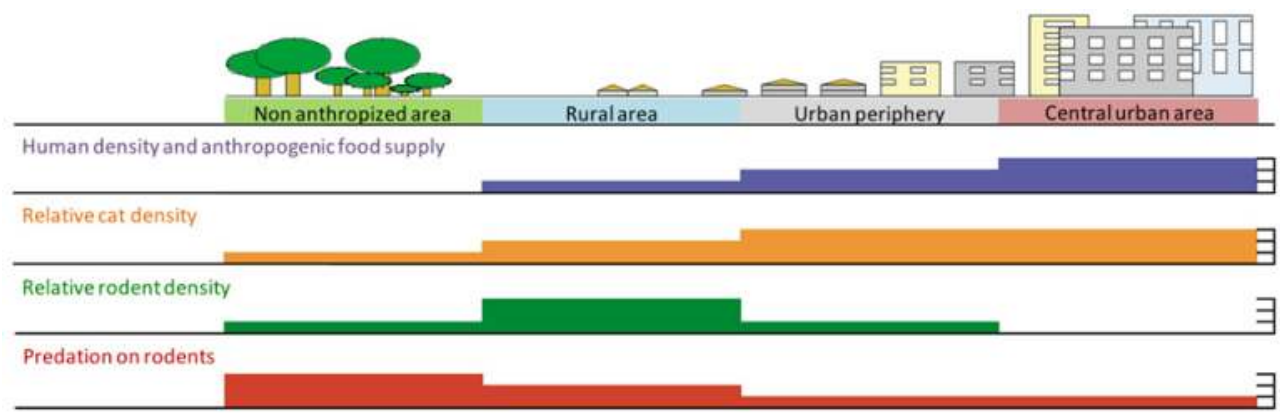

Figure 2. Variations of human density and anthropogenic food supply, cat density, rodent density and predation along an urban-rural-wild gradient. The magnitude of the bars represents the relative importance of each factor according to the degree of urbanization (modified from [4]).

Because of these variations of three key parameters of T. gondii cycle (densities of DHs and IHs, and predation rate), one can hypothesize that the dynamics of $T$. gondii should vary qualitatively and quantitatively along the urban-rural-wild gradient, following the specific features regarding $T$. gondii transmission in each environment. Urban areas, at least in the limited areas where cats live, support the highest densities of DHs. However, in cities, rodent densities are relatively low and predation rate is low due to the availability of anthropogenic food resources. The transmission through predation is not expected to be favoured in this case, but the DH-environment cycle should be maximized. On the contrary, in the wild environment, the level of predation of cats on rodents is maximal, but cat density is low, thus transmission should occur only by predation. Finally, rural areas combine intermediate to high values of $\mathrm{IH}$ and DH density, with high predation rates. Thus these may be the most favourable for the transmission of T. gondii [40]. This transmission should occur largely through "classical" IH-DH transmission, but transmissions among IHs and through a possible DH-environment cycle should also be possible in this case.

\subsection{Variations in $T$. gondii dynamics along the urban-rural-wild gradient}

The hypothesis that the dynamics of $T$. gondii transmission varies along the urban-rural gradient has been tested through a theoretical approach, using an epidemiological model [10]. The aim was to estimate the contributions of the IH-DH and DH-environment cycles in the spread of $T$. gondii according to the predation rate, with stable cat population size. The modelling approach allowed the authors to compare populations differing only by the rate of predation, all else being equal. The model first confirmed that the rural environment (here defined as having predation rates above 21 prey/cat per year [35, 36] is favourable for T. gondii, as transmission increases with the predation rate [10]. Seroprevalences predicted for cats ranged from 33.2 to $83.4 \%$ in the rural environment vs. 6.9 to $33.2 \%$ in urban areas. Moreover, in rural-type areas, the contribution of the IH-DH cycle increases with the predation rate, and may reach $70 \%$ of the transmission (Figure 3). The DH-environment cycle may theoretically be responsible for more than $50 \%$ of the transmission, but only in extremes cases with predation rates lower than 9 prey/cat/yr (Figure 3). It is noteworthy that 
the predicted prey seroprevalences, from 2.4 to $5 \%$ along the gradient, was always low compared to the magnitude of cat seroprevalences.

The cat serological prevalences predicted by [10] agree with values observed along the urban rural gradient: when natural populations (as opposed to heterogeneous samples constituted from veterinary clinics or facilities) are considered, seroprevalences are clearly lower in urban (between $15 \%$ to $26 \%$ [41, 33, 34, 42, 43]) than in rural areas ( $48 \%$ to $87.3 \%$ $[44,30,45,32,42])$. They also reach high values in non-anthropized areas: $51 \%$ in Kerguelen island [46]. In rodents, prevalence is generally low $(0-10 \%[47,46])$, which renders comparisons difficult. High seroprevalences have been occasionally reported in brown rats (70\% in Italy [48]) and in house mice (59\% in rural and sub-urban areas in England [49]). However, these limited data do not permit to draw a clear pattern among environments in rodents. Interestingly, the usually low rodent seroprevalences are in accordance with predictions of the model [10]. The model also suggested that cat seroprevalence is less dependent on prey seroprevalence than on predation rates and prey availability. Thus obtaining accurate estimate of these two last parameters should be more important to understand $T$. gondii epidemiology than estimating rodent seroprevalence.

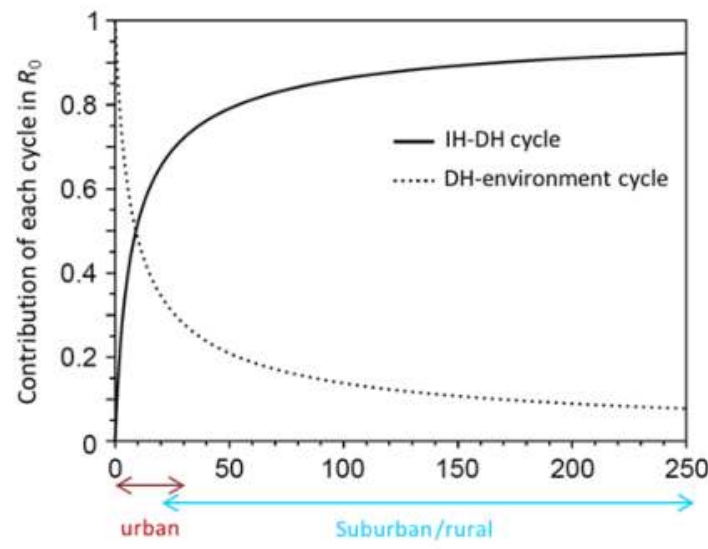

Predation rate, prey/cat per year

Figure 3. Contributions of the DH-Environment and IH-DH cycles in the basic reproductive rate Ro of T. gondii according to the predation rate of IHs by DHs. Predation rates below 27 prey/cat per year represent urban areas, values above 21 prey/cat per year represent rural areas. Modified with permission from [10].

The last way to compare environments would be to compare the levels of soil contamination among environments. However, estimating the level of environmental contamination requires information on the number of new infections in cats (incidence) through longitudinal studies. Based on serological follow-up of cats, incidence was estimated to 0.260.39 infections/cat per year in three rural populations located in France [32]. Incidence was also estimated in one urban site (0.17 infections/cat/year [50]) and in one population living in a non-anthropized environment [46], using the age-seroprevalence relationship. Using data 
on oocyst shedding, Dabritz et al. [51, 52] estimated that 0.04 infections could occur per catyear in cats recruited through local veterinarians in coastal cities in California (USA).

Incidences estimates may be combined to local cat densities, in order determine the number of infection that could occur each year in a given site. In urban sites, even if incidence is low, very high densities of cats lead to expect a high number of infections: 165 infections per $\mathrm{km}^{2}$ per year could occur in the dense population studied by Afonso et al. [41, 50]. In rural sites where cats live in density varying between 120 and 200 cats per $\mathrm{km}^{2}$, [32] estimated that 31 to 72 infections per $\mathrm{km}^{2}$ per year could occur. In Kerguelen, where incidence is high but density is only $1-3$ cats $/ \mathrm{km}^{2}$, the number of new cases per year would be only around $1 / \mathrm{km}^{2} /$ year. Based on the assumption that primary infected cats shed between 1 and 50 millions of potentially infectious oocysts in the environment, oocyst burden may be estimated in each case, as was proposed for rural populations [32]. The results of the cited studies are summarized in Table 1, to give a range of possible estimates for oocyst burden. This may be compared to the estimate from a recent study on owned cats living in coastal California: [51] estimated that the annual burden of oocysts in the environment ranged between 94 and 4671 oocysts $/ \mathrm{m}^{2}$.

The urban-rural-wild gradient is thus a key determinant of the T. gondii dynamics. The general level of transmission varies along this gradient, rural areas being particularly favourable for $T$. gondii transmission. Moreover, the relative importance of different transmission routes is not equivalent along this gradient. In particular, the $\mathrm{DH}$-environment cycle may become significant at very low levels of predation rate, especially in urban areas. These variations are expected to influence the risk for other target species, and especially for people, to get infected. In particular, generally speaking, the level of soil contamination is expected to be highest in the areas where urban feral cats are concentrated, and lowest in the wild environment. However, with each environment, spatial and temporal heterogeneities are present. They will be detailed in the following paragraphs.

\begin{tabular}{|c|c|c|c|}
\hline Population & $\begin{array}{c}\text { Kerguelen } \\
\text { (Non-anthropized) }\end{array}$ & $\begin{array}{c}\text { Aimargues, Saint- } \\
\text { Just Chaleyssin, } \\
\text { Barisey } \\
\text { (Rural) }\end{array}$ & $\begin{array}{c}\text { Lyon Croix- } \\
\text { Rousse } \\
\text { (Urban) }\end{array}$ \\
\hline Seroprevalence in cats (\%) & $36.2-55.0$ & $47.4-55.1$ & 18.6 \\
\hline $\begin{array}{c}\text { Incidence in cats (number } \\
\text { of new infections/cat/year) }\end{array}$ & $0.28-0.65$ & $0.26-0.39$ & 0.17 \\
\hline $\begin{array}{c}\text { Number of new cat } \\
\text { infections/km }\end{array}$ & $0.66-1.3$ & $31-72$ & 165 \\
\hline $\begin{array}{c}\text { Oocyst burden (number } \\
\text { deposited /year/m2) }\end{array}$ & $17-33$ & $775-1800$ & 4125 \\
\hline
\end{tabular}

Table 1. Estimated levels of contamination by oocysts in five populations located in different environments. The table summarizes the studies of one population in a non-anthropized island (2 study sites) [46], three rural populations [32] and one urban population [41]. Oocyst burdens are estimated considering that an infected cat produces 25 millions oocysts. 


\section{Urban toxoplasmosis}

Urban landscapes are characterized by highly fragmented natural or semi-natural habitats resulting in a mosaic of patches varying in size and quality. Dispersal abilities of animal species between patches are generally affected by roads or by distance to the nearest patches $[53,54]$. Many animal species are thus restricted to parks, artificial forest fragments or recreation areas [55]. This results in local extinctions, increased local population density, or social disturbance. Natural populations of domestic cats are present in urban areas in various sites including hospital gardens [56], parks [57, 58], cemeteries or squares [59], taking advantage of the abundance of shelters, food wastes linked to human activity or food provided by cat lovers $[59,17,54]$. Densities regularly exceed 250 cats per $\mathrm{km}^{2}$ [16], and can reach up to 2000 cats per $\mathrm{km}^{2}$ like in urban parks in Italy [58].

In urban areas, rodent densities are heterogeneous and generally strongly related to vegetation cover, predation pressure [29], and/or on how the presence of rodents is controlled by trapping or poisoning. For example, the density of field mouse Apodemus $s p$. can range from no individual in areas occupied by dense populations of predators, to 20,000 individuals per $\mathrm{km}^{2}$ in isolated patches $[28,29]$. Communities of small mammals can persist at high density in small habitat patches sparsely settled by predators [28]. It is therefore unlikely that cat and IHs populations coexist at high densities in the same habitat patches. In addition, urban cats are attracted by food provided by humans, easily accessible all over the year, and that requires no effort of predation. The presence of such a resource can reduce the motivation to hunt in cats $[16,59]$. Observations made on urban cats in hunting activity are thus rare in such areas [41]. The altered predator-prey dynamics limits IH-HD T. gondii transmission, however toxoplasmosis does occur in urban hosts. Most surveys conducted in stray cats show low prevalences ranging from 5 to $20 \%$ [60, 61, 62, 41]. However, high values have occasionally been found: 35.4\% in Sao Paolo [62], 51.9 Barcelona [63], 70.2 in Ghent, Belgium [64]. These cases may correspond to areas where cats have access to predation.

The high local densities of cats also entail a high local level of environmental contamination by $T$. gondii oocysts. Beside density, in such areas, cats often use the same place to defecate where they burry or expose their faeces as scent marks [16, 65], and a single location may be used by several cats when cat density is high [66]. Moreover, this behaviour is expected to favour the direct contamination of cats by oocysts while defecating, since oocyst load in defecating areas is extremely high, and cats are exposed through scratching the soil, before cleaning their paws and fur. These defecation sites spread over cat territory cumulate a high concentration of oocysts in areas closed to humans. A study of a cat population living in the Croix-Rousse hospital (Lyon, France) showed that defecation sites were the areas most often found to be positive for T. gondii DNA, and may be viewed as hot spots of environmental risk to humans [50]. Similarly, in Poland and in China, contaminated soil samples have been found in public parks and sand pits $[67,68]$. Contact with soil, and particularly gardening and consumption of raw vegetables have been demonstrated to be significant risk factors for toxoplasmosis in humans $[69,7,70]$. Contact with defecation sites is thus expected to result in a high risk of infection, but, because contaminated sites represent a low proportion of the 
area, only a few humans are likely to be directly exposed. These persons include children playing in sand pits, persons feeding the cats, gardeners, maintenance workers in these sites and also dog owners who allow pets to roam in these sites and become indirectly exposed through contact with dogs $[71,67,68]$.

Overall, toxoplasmosis in urban areas should be characterized by heterogeneous dynamics, with usually low levels of prevalence in cats, but locally high levels of soil contamination, which may favour the environment-DH cycle.

\section{Heterogeneity in the rural environment}

Rural areas, and in particular agricultural landscapes, are suitable for T. gondii transmission, due to the high densities of both DHs and IHs [72], and to the high level of predation. However, this does not mean that rural areas are evenly infected. Spatial and temporal variations have been detected at several scales. We first present the temporal dynamics to identify mechanisms of heterogeneity that may also explain spatial variations.

\subsection{Temporal dynamics}

A temporal variability in the dynamics of $T$. gondii life cycle has been detected, both at the year-to-year level and between seasons. It is first important to notice that temporal variability is uneasy to study using serological data, because of the lifelong persistence of antibodies. In long-lived species, temporal variations in the rate of appearance of new cases (incidence) may be masked by the persistence of antibodies. The easiest ways to study temporal dynamics of $T$. gondii should be to consider short-lived species, species where antibody response does not persist lifelong, individual serological follow-up, or to consider indicators of acute infection, i.e., type $\mathrm{M}$ immunoglobulins or oocyst excretion in cats.

Due to the difficulty to organize long-term surveys, year-to-year variations have been found in a few populations only: in roe deer Capreolus capreolus in Spain [73] and in Sweden [74], in red deer Cervus elaphus in Scotland [75], as well as in Canadian seals [76]. Tizard et al. [77] performed the largest survey to our knowledge, with nearly 12,000 persons studied over 14 years. This survey revealed inter-annual 6-year cycles and showed that year-to-year variations follow rainfall levels with a correlation coefficient as strong as 0.71 . Accordingly, a longitudinal survey of rural populations of domestic cats in France showed important interannual variations in incidence among years, related to variations in the level of rainfall [32]. In an urban site, seroprevalence in cats was highest during years with a hot and moist weather or with a moderate and less moist weather [41]. The same trend was observed during a long-term follow-up of two populations of roe deer, with maximal seroprevalence under cold/dry, or cool/moist years [78].

The first explanation that has been proposed for the correlation between meteorological conditions and T. gondii dynamics involves the survival of oocysts. The free stage of T. gondii is subject to hard environmental conditions: in the terrestrial environment, its survival in soil depends on temperature and moisture. Oocyst survival is maximal (> 200 days) for 
temperatures comprised between $-6^{\circ} \mathrm{C}$ and $+20^{\circ} \mathrm{C}$ [79]. Above $+20^{\circ} \mathrm{C}$, dessication of oocysts may occur $[41,80,81]$, but moisture should prevent it $[82,83]$. Under- $6^{\circ} \mathrm{C}$, the survival of oocysts is reduced and their capacity to sporulate is lost [79], although one may hypothesize that snow cover may protect them from cold. Meteorological variations are thus expected to determine the survival of oocysts. Oocyst survival has also been demonstrated as one of the parameters that most influence predictions given by a mathematical model [10]. However, other factors may also vary with meteorological conditions and influence $T$. gondii life cycle. In particular, the population dynamics of rodents is affected by climate-driven vegetation growth [84]. Specifically, when winter is mild, survival is high and rodent populations comprise many adult or old individuals, which are the age groups most often infected. Thus the risk of encountering an infected prey is expected to increase after mild winters [32]. This mechanism would contribute to the high transmission of T. gondii after mild winters, in combination with high oocyst survival.

Meteorological conditions are also expected to act at the seasonal level. Oocyst survival should be lowest during dry, hot summer periods, and during very cold winters. Moreover, the population dynamics of hosts follows seasonal cycles: most births of rodents and cats occur in spring and summer. However, since many kittens carry maternal derived antibodies [41], the susceptible populations may increase in summer for rodents and in fall for cats. We thus propose the following pattern (Figure 4): in summer, the low survival of oocysts would lead to a low level of environmental contamination. However, the renewal of the pool of susceptible rodents at the same period may boost $T$. gondii transmission. The proportion of infected rodents would increase during summer and fall, thus increasing the risk for cats to get infected. During fall and winter, kittens would have a maximal risk to get infected and excrete oocysts. Finally, in spring, most cats born during the previous year and highly exposed through hunting would have terminated their oocyst excretion thus the rate of soil contamination would decrease. However, due to the survival of oocysts, the prevalence in rodents would continue to rise, and would reach its maximal value at the beginning of spring when reproduction starts again, giving birth to naïve rodents. Following this scenario, the infection of domestic herbivores would increase at the end of fall and in winter, when cats excrete oocysts, specifically within farm buildings [85], but could continue up to the following spring, due to the high survival of oocysts. The risk for infection of people would thus be maximal in winter when oocyst contamination and herbivore infections are frequent, and may persist up to the following spring.

Because of the methodological difficulties presented above, many studies do not find any seasonal pattern [47], and few data come in support of this hypothesis. Tizard et al., considering only high titres, found a clear decrease of human infections in fall [77]. This decrease was interpreted as a consequence of the dry summer period, corresponding to low oocyst survival. In Serbia, new infections occurred more often between October and April than the rest of the year [86]. A seasonal pattern was also found in the proportion of cat faeces presenting oocysts in Germany. Faeces collected between January and June $(0.09 \%)$ were significantly less often infected than those collected during the second part of the year, between July and December (0.31\%) [87]. These observations are concordant with the above 


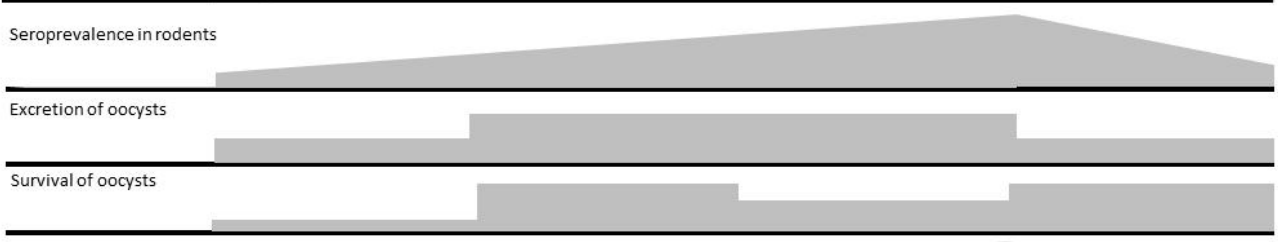

Figure 4. Possible seasonal pattern of the transmission of $T$. gondii.

scenario, however, more detailed data and/or a theoretical approach are needed to fully confirm the proposed pattern. Should this pattern be confirmed, the variability of risk with time should be taken into account for management and prevention recommendations.

\subsection{Spatial heterogeneity}

Spatial heterogeneity of the infection in the rural environment has been demonstrated both between regions and between areas within and around villages. Farm animals, being restrained to agricultural areas, are particularly relevant to analyse spatial heterogeneities of the circulation of T. gondii. However, studies concerning other species or humans may provide useful information when the studied processes concern farms as well as surrounding areas.

At the between-region scale, heterogeneity has essentially been shown to correlate with climatic variations. The hypothesis of relationships between humidity, temperature and $T$. gondii prevalence has been suggested in cattle in Serbia [88] and in sheep in Spain [89]: regions with high humidity and moderate temperatures are considered as most favourable for the sporulation and survival of oocysts. However, few data allowed authors to formally analyse these relationships in farm animals. When comparing the incidence of toxoplasmosis in rural cats living in three villages from distinct regions in France, Afonso et al. found that the difference between the villages was explained by their level of rainfall [32]. Other surveys, considering wild-living species and humans, are in accordance with the hypothesis of a climate-driven dynamics. Regional seroprevalences in woman in France vary with temperature: they increase when mean temperature increases, but decrease when the mean number of days below $-5^{\circ} \mathrm{C}$ increases in the region [13]. In a national survey on the wild boar Sus scrofa, the number of 10-day periods below $-6^{\circ} \mathrm{C}$ was also found as a determinant of T. gondii seroprevalence [90]. Still in the wild boar, in Corsica, prevalence was highest at high altitude, where rainfalls are abundant and temperatures are low [91]. Overall, these and previous results (4.1) underline the importance of climate and meteorological conditions in driving the temporal and spatial dynamics of $T$. gondii. These 
environmental conditions probably also act at a very local scale, for example to affect soil contamination in South-oriented versus North-oriented slopes, however this has not been studied.

Within villages, the spatial organization of host populations leads to heterogeneities of $T$. gondii between central villages, farm areas and fields. In particular, farm buildings and their surroundings, which shelter both cats and IHs, constitute an important source of infection for the surrounding areas. The spatial distribution of cases around a pig farm [72], and a mathematical modelling approach [92] both confirmed that farms represent a source for the whole rural environment. Farms also represent a source of infection for the surrounding wild areas: in Corsica, the seroprevalence in wild boar increased with the density of farms in the county [91].

Finally, the dynamics of $T$. gondii is also variable among farms. As expected, the presence of cats often determines the risk of a farm being infected $[93,94]$, thus cat control is a key to the control of toxoplasmosis in farms [95], as well as rodent control [96]. Other factors reported to influence T. gondii prevalence are related to herd management: size and isolation of herd, presence of a water point, type of feeding $[97,93]$. These factors represent interesting control points [96].

Overall, the rural environment, and in particular farms and their surroundings, are a major source of infection, including for other areas. In particular, rural areas and farms are the gate for T. gondii to circulate between the wild and domestic environments, thus their spatial distribution, management and level of biosecurity are determinant in the possibility for $T$. gondii to mix domestic and sylvatic cycles.

\section{A sylvatic cycle for T. gondii?}

Being able to infect many species, T. gondii is common in wildlife, both in DHs and IHs [2, $98,46,1]$. The question of a sylvatic cycle, and of whether such a cycle would be separated from the transmission in the domestic area, has been raised. A possible interpenetration between domestic and wild cycles would have important consequences for the management of T. gondii, since limiting the propagation of the parasite among domestic animals is only feasible if there is no major wild source. The main tools available to investigate this question are the analysis of genotypes that are present in both areas, and the understanding of transmission pathways through epidemiological surveys.

However, the situation differs between temperate and tropical areas. Section 5.1 reviews the factors associated with $T$. gondii infection in wild animals in temperate areas, and assesses the risk of inter-transmission between domestic and wild cycles with its consequences in terms of zoonotic hazard, animal health and population dynamics of highly susceptible wild species. Section 5.2 shows that in Europe, and to a lesser extent in North America, strains found in wildlife are similar to local strains found in domestic animals and the environment. Finally, section 5.3 deals with the specific situation of tropical areas, where the separation between domestic and wild cycles is clearer than in the temperate areas. 


\subsection{The dynamics of $T$. gondii in wildlife in temperate climates}

T. gondii infection in wildlife does not occur with the same probability in any species or place. Wild-living species first have variable levels of susceptibility and exposure. Exposure is largely determined by life history traits, especially feeding behaviour. In birds, where $T$. gondii infection can be present at a high level in many wild birds without any clinical impact, exposure to T. gondii is highest in carnivorous species [99]. High T. gondii seroprevalence is also reported in large predator species as Lynx and the European wildcat $[100,101]$ which is of epidemiological significance because infected felids shed oocysts in the wild environment.

Among non-carnivorous species, the risk of infection is related to the risk of encountering oocysts, thus to the level of contact with potentially contaminated soil. In rodents and lagomorphs, home-range size, energy requirements and life expectancy are all expected to be related to the probability to encounter T. gondii oocysts. As these traits are correlated to body size $[102,103,104,46]$, large rodents species are more often found positive than small ones [46]. Body size is thus a relevant indicator of prevalence in a given species, and also an indicator of the risk for predators to get infected by preying on that species. Finally, omnivores such as wild boar can acquire toxoplasmosis by incidentally ingesting infected rodents and mainly by rooting and feeding from soil contaminated with oocysts excreted by cats, as shown for other species with similar behaviour, e.g., poultry [105]. On the same way, nutria Myocastor coypus is a terrestrial herbivorous but can also eat small insects that can disseminate oocysts and mussels, which can accumulate oocysts [106, 107, 108]. Nutria and wild boar are thus particularly exposed to infection by T. gondii [109, 110]. Besides being potential source of $T$. gondii for scavengers, they constitute relevant species to monitor the burden of oocysts in the wild environment and to study factors associated with the dynamic of T. gondii infection.

The relationship between feeding behaviour and T. gondii infection may also act within species: in a predator species for example, differences of feeding behaviour between genders can lead to a T. gondii infection higher in one group compared to others. In an insular population, male cats were more often infected than females, which may be related to the fact that males are heavier and may feed on lagomorphs more often than females, which prey mainly on small mammals [46].

Beside species feeding ecology, wild-living populations also have a spatially and temporally structured risk. Like for rural populations (see 4), climatic and meteorological conditions are significant factors explaining the spatio-temporal variations of $T$. gondii in wild populations $[111,91,90,78,112]$. Another determinant factor is the proximity of agricultural activity: in Corsican wild boar, seroprevalence was highest in counties with high farm densities [91]. The presence of domestic cats, including farm cats or feral cats essentially living on predation, and wildcats and hybrid that may live close to rural areas [113], is probably an important factor explaining the connection between the wild and domestic life-cycles of $T$. gondii. Cats roaming into forest or rural landscape searching for preys may shed oocysts and 
contaminate the soil grazed by herbivorous or omnivorous IHs. The domestic-wild interconnection is thus expected to increase with the proportion of predatory cats in populations and their densities. This connection is also expected to increase with landscape fragmentation, which increases the surfaces where wild animals may come in contact with cats habitat. Generally, the level of anthropization is a relevant proxy for the presence of domestic cats and risk of toxoplasmosis in wild-living populations: in Sweden and Finland, the north-South gradient found in ungulates and hares, respectively, has been interpreted as the result of a declining presence of human settlements and cats in the North [74, 114, 115]. In Chile, the prevalence in American minks Neovison vison was highest at proximity of human settlements [116]. Finally, when wild-living cats are present, they constitute a strong determinant of T. gondii in wildlife: at the national level, $T$. gondii prevalence in French wild boar is high in the area of presence of the European wildcat Felis silvestris [90]; in Alaska, the prevalence of infection in herbivorous species reflects the distribution of lynx Felis canadensis in the area [117]. Here it is important to underline that, in order to find relevant explanatory spatial factors, these have to be measured at the appropriate scale. For example, farm density may not be an appropriate estimator of the domestic cat population when considered at the country level [90]. Similarly, as stated earlier (4.2.), oocyst survival depends on the conditions experienced by oocysts in their microenvironment, whose range can be lower than the home range of the studied host population, and also lower than the scale at which meteorological data are usually obtained [90]. The difficulty to obtain data at the right spatial scale may explain that some spatial patterns were not elucidated [118, 119].

On the other hand, the presence of cats or anthropized area is not the single way remote areas may be contaminated. Within the natural environment, long-distance dispersal of $T$. gondii is possible either as oocysts or cysts within IHs. An example of the first process is the contamination of marine mammals along the Northern Pacific American coast. Genetic as well as epidemiological studies suggest that southern sea otters Enhydra lutris nereis may be contaminated following fecal contamination of soil by domestic and wild felids flowing from land to sea through surface runoff, followed by the accumulation of oocysts in filterfeeding marine invertebrates [120]. The dispersal of oocysts within the marine environment is poorly known, but Massie and al. [121] recently proposed that migratory filter-feeding fish, like northern anchovies Engraulis mordax and Pacific sardines Sardinops sagax, may spread T. gondii throughout the ocean. On the other hand, the long-distance dispersal of $T$. gondii within IHs may be illustrated in the case of the isolated archipelago of Svalbard, where cats are absent. In this area, arctic foxes were found to carry $T$. gondii, whereas 751 grazing herbivores tested were all seronegative, indicating that contamination by oocysts is uncommon in the area. Prestrud et al. $[122,123]$ proposed that T. gondii may have been transported to arctic area by migratory birds.

All these processes act to spread T. gondii from domestic to wild, and within the wild environment. A possible consequence of this large transmission is the threat on conservation efforts of highly susceptible species [124]. In most species, T. gondii infection is generally 
unapparent, provoking only mild symptoms. However, a limited number of highly susceptible species have been discovered, in which $T$ gondii infection leads to frequent clinical disease and mortality. Marsupials and New World monkeys, which have evolved largely separately from cats, are among the most vulnerable species [2, 125]. Fatal toxoplasmosis is also well-documented in hares (Lepus sp.), in northern Europe [114] and Japan [126]. Hares that die of toxoplasmosis are in general in a normal nutritional state and the disease is acute. The explanations for the failure to achieve equilibrium between the host and parasite mainly focus on the host characteristics: a possible lack of cellular immune response [127, 128], the negative impact of stress (food and diet disturbances, exposure to cold, concurrent infections) on the immune response of this species, or even the cumulative effect of immunosuppression induced by toxoplasmosis and stress [129] have been proposed. A clinical expression of toxoplasmosis is also observed in a felid, the Pallas' cats Otocolobus manul when raised in captivity [130, 131]. In fact, wild Pallas' cats have minimal opportunity for exposure to T. gondii in their isolated natural habitat in Central Asia and, typically, do not become infected with this parasite until being brought into captivity. This could explain their extreme susceptibility to toxoplasmosis [132], which could threaten conservation programs devoted to this species [133]. Although no specific case has been documented in the wild, T. gondii may threaten local wild-living populations, for example when new human settlements come in contact with isolated endangered populations.

\subsection{T. gondii strains in wildlife at temperate latitudes}

Despite the presence of a sexual cycle, T.gondii maintains a highly clonal population structure. The majority of isolates found belong to one of the three clonal lineages referred to as type I, II and III [134]. Recently, a fourth clonal lineage, called haplogroup 12, has been identified based on isolates from wildlife in the United States [135].

In Europe, the majority of isolates from wildlife contain type II strains, with a few type III strains. From 26 T. gondii positive extracts from red fox Vulpes vulpes from Belgium submitted to a genotyping analysis with 15 microsatellite markers [136], 25 were type II and only one type III [137]. Similarly, using six loci microsatellite analysis, only type II strains were observed in 46 French isolates including 21 from wild boar [138], 12 from roe deer, 9 from foxes, one from mouflon Ovis aries, red deer and mallard Anas platyrhynchos [139] and one from tawny owl Strix aluco [140]. Using the same molecular technique, Jokelainen et al. [141] also identified the clonal type II in 15 DNA extracts from hare (Lepus sp.) in Finland. In a recent study in Central and in Eastern Germany, Hermann et al. [87] determined the complete genotype has been determined for twelve samples tissues from red foxes, using nine PCR-RFLP markers. In addition to T. gondii clonal type II apico II and apico I, type III and T. gondii showing non-canonial allele pattern were observed. Interestingly, this study showed evidence of a mixed infection, as well as infection with a T. gondii genotype that may represent a recombination of T. gondii types II and III. 
Su et al. [142] developed a standardized restriction fragment length polymorphism (RFLP) typing scheme based on nine mostly unlinked nuclear genomic loci and one apicoplast marker. These markers enable one to distinguish the archetypal from atypical types. In addition, mixed strains in samples can be easily detected by these markers. Mixed infection of T. gondii strains in IHs has been previously reported [134, 143]. Detection of mixed infection is of particular interest in epidemiological studies. For genetic exchange, the DH must ingest different types of parasites from their prey at nearly the same time. The frequency of mixed infections in IHs is a relevant indicator of the likelihood of the genetic exchange to occur in the field. In Svalbard, a Norvegian arctic archipelago, 55 artic foxes Vulpes lagopus were found infected with T. gondii: 27 (49.1\%) harboured clonal type II (17/27 were apico I and 10/27 apico II) and four (7.3\%) had clonal type III [123]. Strains from 22 foxes $(40 \%)$ could not be fully genotyped, but two (3.6\%) shared more than one allele at a given locus. Again, the most prevalent genotype in this study was clonal type II (with apico alleles I and II) with a few types III genotypes.

It is noteworthy that type II is also the dominant type in domestic mammals in Europe. For instance, Dumètre et al. [144] showed by multilocus microsatellite analysis the predominance of type II in sheep, which has also been previously described in humans. In the same way, Halos et al. [145] analysed 433 hearts of sheep by using PCR-restriction fragment length polymorphism and microsatellite markers on parasites isolated after bioassay in mice. All 46 genotypes belonged to type II, except for one strain from the Pyrenees mountains area, which belonged to genotype III, which is the first non-type II genotype found in sheep in Europe [146], Denmark [147] and France [144]. This similarity between strains found in wildlife and domestic species in Europe suggests that no clear separation exists between the two cycles.

In North America, strains of T. gondii are more diverse. A recent study [148] analysed $169 \mathrm{~T}$. gondii isolates from various wildlife species including DHs and IHs, and revealed the large dominance of a recently designated fourth clonal type, called type 12 , followed by the type II and III lineages. These three major lineages accounted for $85 \%$ of strains from wildlife in North America [148]. The strains isolated from wildlife in North America are thus more diverse, but may also be more different from strains found in the domestic environment than in Europe. Although type 12 has been identified from pigs and sheep in the USA, it may be more specifically found in wildlife [135]. The relative high diversity in T. gondii genotypes isolated from wildlife samples compared to those from domestic animals raised the question as to whether distinct gene pools exist for domestic and sylvatic hosts [149].

\subsection{The wild environment in tropical areas}

The wild environment in tropical areas is still characterized by high fauna diversity, and large areas preserved from influence of humans and of domesticated animals, including cats. Studies on T. gondii seroprevalence conducted on tropical wild animals, mainly in South America, show the wide circulation of T. gondii in the wild environment of these 
countries. As in temperate climate [150], the prevalence of T. gondii infection was higher in carnivorous or carrion-eaters, or those that accidentally consume oocysts while foraging for food on the ground than in arboreal animals [151]. It was also remarkably high in aquatic mammals such as free-living Amazon River dolphins Inia geoffrensis [152]. Remote human population living in wild environment may also exhibit high seroprevalence level for $T$. gondii infection, for example $60.4 \%$ in Amerindian tribes [153] or 38.9\% in Pygmies from Central Africa [154]. As domestic cats are generally absent from this environment, wild felids are the main source of water and soil contamination. Thirty-nine species of felids have been described, of which 20 live in humid tropical areas [155, 156]. The capacity of oocyst excretion has been demonstrated in captivity, and high seroprevalences were found on freeliving felids [157]. In captive Neotropical felids from Southern Brazil, wild-caught felids were three-times more likely to be infected when compared to zoo-born animals [158]. The different species of wild felids varied in home range and resource requirements, but they generally have larger hunting areas and dietary intake than domestic cats, especially the largest ones [159]. This could result in a high opportunity to ingest T. gondii infected preys. So, despite the fact that the ecology of $T$. gondii in the wild tropical environment has been poorly studied, the different behaviour of wild felids compared to that of domestic cats and the number of possible IHs suggest a complex ecology of this parasite in this environment leading to a high genetic diversity [160].

This high genetic diversity in tropical wild-life in connection with a sylvatic life cycle has been firstly evoked in French Guiana where severe cases of human toxoplasmosis were detected after eating Amazonian undercooked game or drinking untreated river water [161, 162, 163]. These cases were due to highly atypical strains, all with unique genotype, as determined by microsatellite analysis [164]. The difference between these strains acquired from the Amazonian environment and strains from the anthropized environment of French Guiana was further documented by strain sampling in animals from the different compartments [165].

Compared to the strains of the anthropized environment, the "wild" strains from the Amazonian rainforest in the Guianas exhibited a remarkably high genetic diversity [162, $164,165]$. Whereas the majority of strains from the adjacent anthropized environment are clustered into a few widespread lineages, the "wild" population of strains does not exhibit any clear genetic clustering/structure nor any linkage disequilibrium, supporting the hypothesis of an important circulation and mixing in this environment. This could be connected to the high level of biodiversity in Amazonian neotropical rainforest. This biodiversity concerns the different protagonists of $T$. gondii life cycle $(\mathrm{DH}, \mathrm{IH}$ and environment). This part of the world may be considered as one of the most important hotspot of diversity with at least 183 mammal species, including 8 of thirty nine known wild felid species, and 718 bird species in French Guiana [165]. The corresponding high level of diversity among T. gondii strains may reflect the "natural" population structure of this parasite (before the time of domestication of cats and development of farming) within the 
true complexity of less disturbed ecosystems. The relative richness of potential hosts that exists within the tropics may have resulted in a correspondingly more diverse range of genotypes of the parasite that can co-exist in such an environment. Under this hypothesis, $T$. gondii would have developed a plurality of alleles to increase its colonization potential [160, 162]. In addition, the larger home ranges of wild felids compared to domestic cats can also strongly influence hybridization patterns and gene flow of the parasite and thus the genetic structure of pathogen populations. The high prevalence in IHs, added to wild felid ecology (diet and home range), could suggest that DHs are more frequently infected by multiple $T$. gondii genotypes, which then cross and recombine before transmission to a new IH. The possibility of reinfection by different strains is known for humans [166]. It has never been explored for felids, but may be hypothesized as another source of increasing diversity.

Most tropical countries are also characterized by an ongoing anthropization with development of farming and settlement in deforested areas. At the confluence between the two environments, wild animals may penetrate in anthropized areas and domestic animals come in contact with the wild through wild game, soil or running water. The increasing pressure of anthropization reduces the hunting area of wild carnivores, including felids and favours their penetration in domestic area. The predatory activity of wild felines or stray cats around these disturbed environments (consumption of chickens, dogs, cats...) would ensure gene flow between the two populations of strains. The consequences of this interpenetration in terms of $T$. gondii genotypes are diverse: (i) detection of $T$. gondii strains with "hybrid" genotypes between the "wild" population and the anthropized population reflecting genetic exchanges, (ii) strains from the wild environment found in domestic animals, such as stray dogs, or (iii), on the opposite, strains from the anthropized environment found in wild animals [165]. In parallel, the influence of human activities with urbanization, fragmentation of landscape, deforested areas, farming, domestication of cats and other animals, modifies T. gondii ecology reducing the number of ecological niches. This process favours an impoverishment of $T$. gondii genetic diversity with the selection of a few strains well adapted to a small number of domestic species [167, 168]. Transportation of these strains through large distances by human trade exchange and transportation of animals lead to introduction of domestic strains in the wild environment and occasionally to expansion of clonal lineages. In tropical countries, this is evidenced by the so-called Caribbean genotypes found in the anthropized areas of French Guiana and in several Caribbean Islands, or in Africa, where the same African lineages were found in different countries $[169,170,171]$.

Finally, the dynamics of T. gondii in wildlife and its interaction with domestic areas show a contrasted pattern. In most European countries, due to the large anthropization, any wildliving individual lives relatively close to domestic areas. Farming and cat domestication occurred long time ago. Farms constitute the reservoir of infection, from which a few genotypes adapted to farm species irradiate in the surrounding environment [72]. This could explain the widespread occurrence of only a few well adapted clonal lineages (types II 
and III) even in wild animals. In other temperate or cold countries, such as the U.S.A. or Canada where large territories are non-anthropized, the genotypic diversity of T. gondii in the wild animals is present $[148,149,172]$. The diversity is maximal in tropical areas, due to high host diversity and large non-anthropized areas. Thus the risk of transmission of toxoplasmosis from wildlife has not the same consequences everywhere. In tropical areas, specific "wild" strains may be transmitted, thus the transmission risk is relatively easy to characterize through strain genotyping, while in Europe, a case of infection acquired from wildlife would pass unnoticed due to the similarity of strains. The risk of infection from wildlife may be analyzed through genotyping strains in tropical areas, but through epidemiological surveys in Europe.

\section{Conclusion: consequences for the management of zoonotic transmission}

Like other IHs, humans can be infected either by cysts containing bradyzoits, or by oocysts of T. gondii. Tissue cysts are responsible for meat-borne infection (pork, lamb, beef or poultry are possible source of contamination), while sporulated oocysts lead to infection by ingesting particles of soil (after gardening for example) or by consuming unwashed raw fruits or vegetables, or untreated water $[2,145,173,174,175]$. However, the crucial question of the relative part of risk related to bradyzoits versus oocysts remains open. Different approaches have been used to estimate the relative importance of sources of contamination, using risk-factor analyses or estimation of the fraction of attributable risk, either in the general population (chronic infection) or in cases of seroconversion in pregnant women. These studies clearly identified the ingestion of undercooked meat as a risk factor $[7,13,173$, 176]. However, this result is probably partly due to this risk being easier to characterize than the risk due to oocysts. Another way to get an idea of the relative part of risk related to cysts or oocysts is to undertake a quantitative assessment of the risk of toxoplasmosis [177]. Recently, in the Netherlands, Opsteegh et al. performed a quantitative microbial risk assessment (QMRA) for meat-borne toxoplasmosis, which predicted high numbers of infections per year. The study also demonstrated that, even with a low prevalence of infection in cattle, consumption of beef constitutes an important source of infection [178]. However, the risk assessment remains limited by the lack of detailed information on which fraction of meat is more contaminated in carcass: although seroprevalences are available for farm animals from many countries [2], the correlation between seropositivity and detection of parasites in meat is weak. In terms of veterinary medicine, there is no surveillance system for animal toxoplasmosis and only cases of abortions (due to T. gondii or other causes) have to be declared. The meat-borne risk analysis is also limited by the low level of information on the food cooking practices, and on the contamination of species consumed less often, such as game $[90,91,78]$.

Up to now, the risk analyses essentially used information on, and produced estimates about, meat-borne toxoplasmosis. These studies permitted to identify control points for the 
management of meat-producing animals. For example, in intensively managed swine farms, modern biosecure management practices have resulted in reduced levels of infection in swine raised in confinement $[96,179,180]$. In organic livestock production systems, farmmanagement factors including feeding are thought to play an important role in the on-farm prevalence of $T$. gondii [181]. To limit T. gondii infection in such farms, recommended practices include exclusion of cats or other wildlife, strict rodent control and restriction of human entry in pig barns [182]. These measures could be effective in other species to reduce the level of contamination of meat. On the contrary, organic pork meat may pose a specific risk of transmitting T. gondii to humans [183]. However, due to the capacity of dissemination of $T$. gondii, the objective of a completely $T$. gondii-free meat seems difficult, but feasible using pre-harvest measures for prevention of T. gondii infection [184].

On the other hand, working to reduce the level of infection in meat does not act on the risk of toxoplasmosis due to direct contact with oocysts, which stays largely unknown and unmanaged. Limiting the level of contamination in meat may even result in the increase of the relative risk due to oocysts. The importance of oocysts in the overall contamination rate remains difficult to assess, due to the lack of information on the level of environmental contamination and to the difficulty to characterize the level of contact of people with contaminated areas. In this framework, a better knowledge of the life cycle of $T$. gondii in its natural environment should help to characterize the risk due to oocysts. For example, the estimates provided in Table 1 give an order of magnitude of the expected differences between environments. Moreover, two recent methodological advances should improve our knowledge of environmental contamination. First, new methods to detect oocysts in soil [185] and water [186, 187, 188] have been proposed, based on molecular detection or immunocapture. Being highly sensitive, these methods should allow researchers to better characterize areas and periods at risk of contamination. A few studies have already measured the level of soil and water contamination [50,68, 189]. These studies confirmed that the risk in urban areas is spatially structured at the very local scale, and they should help to identify areas most contaminated in other environments. The second useful tool that should bring relevant information is the development of methods to detect antibodies specifically linked to infection by oocysts [190]. This test, based on western blot assay detecting for IgG positive serums antibodies to sporozoites, allowed the authors to determine the proportion of cases that had contacts with oocysts in Chile, both in humans [191] and in swine [192]. In North America, a survey using this method shows that a high proportion of mothers of congenitally infected infants had primary infection with oocysts [193].

These new analytical tools should help to identify the origin of contamination, and thus solve several fundamental and practical questions regarding T. gondii life cycle. For example, estimating the frequency of infection from oocysts in cats of urban and rural area should help to estimate the part of the DH-environment life cycle in different environments. In people, these tools should help to assess if the relative role of oocyst and meat-born infection varies according to the area (urban versus rural populations for example). In such 
case, prevention measures should focus on specific aspects depending on the exposure of people. These elements should help to reduce the burden of toxoplasmosis in human and animal populations.

\section{Author details}

Emmanuelle Gilot-Fromont ${ }^{1,2,}$, , Maud Lélu ${ }^{3}$, Marie-Laure Dardé, ${ }^{4}$ Céline Richomme ${ }^{5}$, Dominique Aubert $^{6}$, Eve Afonso ${ }^{7}$, Aurélien Mercier ${ }^{4}$, Cécile Gotteland ${ }^{1,6}$, Isabelle Villena ${ }^{6}$ ${ }^{1}$ UMR CNRS 5558 Laboratoire de Biométrie et Biologie Evolutive, Université Lyon 1, Villeurbanne, France.

${ }^{2}$ VetAgro-Sup Campus Vétérinaire, Université de Lyon, Marcy l'Etoile, France, ${ }^{3}$ NIMBioS, University of Tennessee, Knoxville, Tennessee, USA, ${ }^{4}$ INSERM UMR1094, Tropical Neuroepidemiology, School of Medicine, Institute of Neuroepidemiology and Tropical Neurology, CNRS FR 3503 GEIST, University of Limoges, Limoges, France,

${ }^{5}$ ANSES, Nancy laboratory for rabies and wildlife, Technopole agricole et vétérinaire, Malzéville, France, ${ }^{6}$ Laboratoire de Parasitologie-Mycologie, EA 3800, UFR de Médecine, SFR Cap Santé, FED 4231, University of Reims Champagne-Ardenne, Reims, France, ${ }^{7}$ Department Chrono-environnement, UMR CNRS 6249 USC INRA, University of Franche-Comté, Besançon, France

\section{Acknowledgement}

The authors thank Aurélien Dumètre, René Ecochard, Michel Langlais, Dominique Pontier, Philippe Thulliez and Stéphane Romand for their help in elaborating the 10-year research period that produced part of the results presented here. This project has been supported by the Agence Française de Sécurité Sanitaire de L'Environnement et du Travail (AFSSET) and by the Agence De l'Environnement et de la Maitrise de l'Energie (ADEME), with additional grants from Grünenthal France Laboratory (EA), Institut National de la Recherche Agronomique (INRA, CR), Région Champagne-Ardenne (EA, ML and CG), Département des Ardennes (ML), Communauté de Communes de l'Argonne Ardennaise (ML) and the National Institute for Mathematical and Biological Synthesis (NIMBioS, sponsored by the National Science Foundation, the U.S. Department of Homeland Security, and the U.S. Department of Agriculture, ML).

\section{References}

[1] Dubey JP (2010) Toxoplasmosis of animals and humans, second edition. Boca Raton: CRC Press. 313 p.

\footnotetext{
${ }^{*}$ Corresponding Author
} 
[2] Tenter AM, Heckeroth AR, Weiss LM (2000) Toxoplasma gondii: from animals to humans. Int. j. parasitol. 30: 1217-1258.

[3] Miller MA, Miller WA, Conrad PA, James ER, Melli AC, Leutenegger CM, Dabritz HA, Packham AE, Paradies D, Harris M, Ames J, Jessup DA, Worcester K, Grigg ME (2008) Type $\mathrm{X}$ Toxoplasma gondii in a wild mussel and terrestrial carnivores from coastal California: new linkages between terrestrial mammals, runoff and toxoplamosis of sea otters. Int. j. parasitol 58: 928-937.

[4] Deplazes P, Hegglin D, Gloor S, Romig T (2004) Wilderness in the city: the urbanization of Echinococcus multilocularis. Trends parasitol $20: 77-84$.

[5] House PK, Vyas A, Sapolsky R (2011) Predator cat odors activate sexual arousal pathways in brains of Toxoplasma gondii infected rats. PLoS ONE 6: e23277.

[6] Dass SAH, Vasudevan A, Dutta D, Soh LJT, Salposky RM, Vyas A (2011) Protozoan parasite Toxoplasma gondii manipulates mate choice in rats by enhancing attractiveness of males. PLoS ONE 6: e27229.

[7] Cook AJC, Gilbert RE, Buffolano W, Zufferey J, Petersen E, Jenum PA, Foulon W, Semprini AE, Dunn DT (2000) Sources of Toxoplasma infection in pregnant women: European multicentre case-control study. Br. med. j. 321: 142-147.

[8] Beverly JKA (1959) Congenital transmission of toxoplasmosis through successive generations of mice. Nature 183: 1348-1349.

[9] Dubey JP (2006) Comparative infectivity of oocysts and bradyzoites of Toxoplasma gondii for intermediate (mice) and definitive (cats) hosts. Vet. parasitol. 140: 69-75.

[10] Lélu M, Langlais M, Poulle ML, Gilot-Fromont E (2010) Transmission dynamics of Toxoplasma gondii along an urban-rural gradient. Theor. popul. biol. 78: 139-147.

[11] Berenreiterova M, Flegr J, Kubena AA, Nemec P (2011) The Distribution of Toxoplasma gondii Cysts in the Brain of a Mouse with Latent Toxoplasmosis: Implications for the Behavioral Manipulation Hypothesis. PLoS One 6: e28925.

[12] Pappas G, Roussos N, Falagas ME (2009) Toxoplasmosis snapshots: Global status of Toxoplasma gondii seroprevalence and implications for pregnancy and congenital toxoplasmosis. Int. j. parasitol. 39: 1385-1394.

[13] Berger F, Goulet V, Le Strat Y, Desenclos JC (2008) Toxoplasmose chez les femmes enceintes en France : évolution de la séroprévalence et de l'incidence et facteurs associés, 1995-2003. Bulletin Epidemiologique Hebdomadaire 14-15: 117-121.

[14] Gilot-Fromont E, Riche B, Rabilloud M (2009) Seroprevalence of Toxoplasma gondii in a rural population in France: detection of a household effect. BMC infect. dis. 9: 76.

[15] Haydon DT, Cleaveland S, Taylor LH, Laurenson K (2002) Identifying Reservoirs of Infection: A Conceptual and Practical Challenge. Emerg. infect. dis. 8: 1468-1473.

[16] Turner DC, Bateson PB (2000) The Domestic cat: the biology of its behaviour. Cambridge University Press.

[17] Macdonald DW (1983) The ecology of carnivore social behaviour. Nature 301: 379-384.

[18] Page RJC, Ross J, Bennett DH (1993) Home ranges of feral cats at Avonmouth Docks (United Kingdom). Rev. sci. tech. OIE 12: 23-26.

[19] Calhoon RE, Haspel C (1989) Urban cat populations compared by season, subhabitat and supplemental feeding. J. anim. ecol. 58: 321-328. 
[20] Liberg O (1980) Spacing pattern in a population of rural free-roaming domestic cats. Oikos 35: 336-349.

[21] Pontier D, Rioux N, Heizmann A (1995) Evidence of selection on the orange allele in the domestic cat Felis catus: the role of social structure. Oikos 73: 299-308.

[22] Fromont E, Artois M, Pontier D (1998) Epidemiology of feline leukemia virus (FeLV) and structure of domestic cat populations. J. wildl. manage. 62: 978-988.

[23] Liberg O (1981) Predation and social behaviour in a population of domestic cats. An evolutionary perspective. Ph. D. Thesis, Univ. Lund (Sweden), 135 p.

[24] Liberg O (1984) Food habits and prey impact by feral and house-based domestic cats in a rural area in southern Sweden. J. mammal. 65: 424-432.

[25] Say L, Gaillard JM, Pontier D. (2002) Spatiotemporal variation in cat population density in a sub-Antarctic environment. Polar biol. 25: 90-95.

[26] Say L, Devillard S, Natoli E, Pontier D (2002) The mating system of feral cats (Felis catus L.) in a sub-Antarctic environment. Polar biol. 25: 838-842.

[27] Le Louarn H, Quéré JP (2003) Les Rongeurs de France. Faunistique et biologie. INRA éditions, Paris, 256pp.

[28] Dickman CR, Doncaster CP (1987) The Ecology of Small Mammals in Urban Habitats. I. Populations in a Patchy Environment. J. anim. ecol. 56: 629-640.

[29] Baker PJ, Ansell RJ, Dodds PAA, Webber CE, Harris S (2003) Factors affecting the distribution of small mammals in an urban area. Mammal rev. 33: 95-100.

[30] Dubey JP, Saville WJA, Stanek J, Reed SM (2002) Prevalence of Toxoplasma gondii antibodies in domestic cats From rural Ohio. J. parasitol. 88: 802-803.

[31] Miró G, Montoya A, Jimenez S, Frisuelos C, Mateo M, Fuentes I (2004) Prevalence of antibodies to Toxoplasma gondii and intestinal parasites in stray, farm and household cats in Spain. Vet. parasitol. 126: 249-255.

[32] Afonso E, Thulliez P, Gilot-Fromont E (2010) Local meteorological conditions, dynamics of seroconversion to Toxoplasma gondii in cats (Felis catus) and oocyst burden in a rural environment. Epidemiol. infect. 138: 1105-1113.

[33] Wu SM, Zhu XQ, Zhou DH, Fu BQ, Chen J, Yang JF, Song HQ, Weng YB, Ye DH (2011) Seroprevalence of Toxoplasma gondii infection in household and stray cats in Lanzhou, northwest China. Parasites \& Vectors 4: 214-218.

[34] Zhang H, Zhou DH, Zhou P, Lun ZR, Chen XG, Lin RQ, Yuan ZG, Zhu XQ (2009) Seroprevalence of Toxoplasma gondii infection in stray and household cats in Guangzhou, China. Zoonoses public health 56: 502-505.

[35] Barratt DG (1998) Predation by house cats, Felis catus (L.), in Canberra, Australia. II. Factors affecting the amount of prey caught and estimates of the impact on wildlife. Wildlife res. 25: 475-487.

[36] Baker PJ, Bentley AJ, Ansell RJ, Harris S (2005) Impact of predation by domestic cats Felis catus in an urban area. Mammal rev. 35: 302-312.

[37] Woods M, McDonald RA, Harris S (2003) Predation of wildlife by domestic cats Felis catus in Great Britain. Mammal rev. 33: 174-188.

[38] Gillies C, Clout M (2003) The prey of domestic cats (Felis catus) in two suburbs of Auckland City, New Zealand J. zool. 259: 309-315. 
[39] Kays RW, DeWan AA (2004) Ecological impact of inside/outside house cats around a suburban nature reserve. Anim. conserv. 7: 273-283.

[40] Rosenthal BM (2009) How has agriculture influenced the geography and genetics of animal parasites? Trends parasitol. 25: 67-70.

[41] Afonso E, Thulliez P, Gilot-Fromont E (2006) Transmission of Toxoplasma gondii in an urban population of domestic cats (Felis catus). Int. j. parasitol. 36: 1373-1382.

[42] Hornok S, Edelhofer R, Joachim A, Farkas R, Berta K, Repasi A, Lakatos B (2008) Seroprevalence of Toxoplasma gondii and Neospora caninum infection of cats in Hungary. Acta vet. hung. 56: 81-88.

[43] Lee SE, Kim NH, Chae HS, Cho SH, Nam HW, Lee WJ, Kim SH, Lee JH (2011) Prevalence of Toxoplasma gondii infection in feral cats in Seoul, Korea. J. parasitol. 97, 153-155.

[44] Dubey JP, Weigel RM, Siegel AM, Thuilliez P, Kitron UD, Mitchell MA, Mannelli A, Mateus-Pinilla NE, Shen SK, Kwok OCH, Todd KS (1995) Sources and reservoirs of Toxoplasma gondii infection on 47 swine farms in Illinois. J. parasitol. 81: 723-729.

[45] Cavalcante GT, Aguiar DM, Chiebao D, Dubey JP, Ruiz VLA, Dias RA, Camargo LMA, Labruna MB, Gennari SM (2006) Seroprevalence of Toxoplasma gondii antibodies in cats and pigs from rural Western Amazon, Brazil. J. parasitol. 92: 863-864.

[46] Afonso E, Thulliez P, Pontier D, Gilot-Fromont E (2007) Toxoplasmosis in prey species and consequences for prevalence in feral cats: not all prey species are equal. Parasitology 134: 1963-1971.

[47] Dabritz HA, Miller MA, Gadner IA, Packham AE, Atwill ER, Conrad PA (2008) Risk factors for Toxoplasma gondii infection in wild rodents from central coastal California and a review of T. gondii prevalence in rodents. J. parasitol. 94: 675-683.

[48] Genchi G, Polidori GA, Zaghini L, Lanfranchi P (1991) Aspetti epidemiologici della toxoplasmosi nell'allevamento intensivo del suino. Arch. vet. ital. 42, 105-111.

[49] Marshall PA, Hughes JM, Williams RH, Smith JE, Murphy RG, Hide G (2004) Detection of high levels of congenital transmission of Toxoplasma gondii in natural urban populations of Mus domesticus. Parasitology 128: 39-42.

[50] Afonso E, Lemoine M, Poulle ML, Ravat MC, Romand S, Thulliez P, Villena I, Aubert D, Riche B, Rabilloud M, Gilot-Fromont E (2008) Spatial distribution of soil contamination by Toxoplasma gondii in relation to cat defecation behaviour in an urban area. Int. j. parasitol. 38: 1017-1023.

[51] Dabritz HA, Miller, Atwill ER, Gardner IA, Leutenegger CM, Melli AC, Conrad PA (2007) Detection of Toxoplasma gondii-like oocysts in cat feces and estimates of the environmental oocyst burden. J. am. vet. med. assoc. 231: 1676-1684.

[52] Dabritz HA, Atwill ER, Gardner IA, Miller MA, Conrad PA (2006) Outdoor fecal deposition by free-roaming cats and attitudes of cat owners and nonowners toward stray pets, wildlife, and water pollution. J. am. vet. med. assoc. 229: 74-81.

[53] Forman RTT, Godron M (1986) Landscape ecology. Wiley and Sons, New York, USA.

[54] McKinney ML (2002) Urbanization, biodiversity, and conservation. BioScience 52: 883890. 
[55] Bradley CA, Altizer S (2007) Urbanization and the ecology of wildlife diseases. Trends ecol. evol. 22: 95-102.

[56] Zaunbrecher KI, Smith RE (1993) Neutering of feral cats as an alternative to eradication programs. J. am. vet. med. assoc. 203: 449-452.

[57] Neville PF, Remfry J (1984) Effect of neutering on two groups of feral cats. Vet. rec. 114: 447-450.

[58] Natoli E (1985) Spacing pattern in a colony of urban stray cats (Felis catus L.) in the historic centre of Rome. Appl. anim. behav. sci. 14: 289-304.

[59] Haspel C, Calhoon RE (1989) Home ranges of free ranging cats (Felis catus) in Brooklyn, New York. Can. j. zool. 67: 178-181.

[60] Salant H, Spira DT (2004) A cross-sectional survey of anti-Toxoplasma gondii antibodies in Jerusalem cats. Vet. parasitol. 124: 167-177.

[61] Jittapalapong S, Nimsupan B, Pinyopanuwat N., Chimnoi W, Kabeya H, Maruyama S (2006) Seroprevalence of Toxoplasma gondii antibodies in stray cats and dogs in the Bangkok metropolitan area, Thailand. Vet. parasitol. 145: 138-141.

[62] Pena HJF, Soares RM, Amaku M, Dubey JP, Gennari SM (2006) Toxoplasma gondii infection in cats from Saõ Paulo state, Brazil: seroprevalence, oocyst shedding, isolation in mice, and biologic and molecular characterization. Res. vet. sci. 81: 58-67.

[63] Gauss CBL, Almeria S, Ortuno A, Garcia F, Dubey JP (2003) Seroprevalence of Toxoplasma gondii Antibodies in Domestic Cats from Barcelona, Spain. J. parasitol. 89: 1067-1068.

[64] Dorny P, Speybroeck N, Verstraete S, Baeke M, De Becker A, Berkvens D, Vercruysse J (2002) Serological survey of Toxoplasma gondii, feline immunodeficiency virus and feline leukaemia virus in urban stray cats in Belgium. Vet. rec. 151: 626-629.

[65] Corbett LK (1979) Feeding ecology and social organization of wildcats (Felis silvetris) and domestic cats (Felis catus) in Scotland. Scotland: University of Aberdeen.

[66] Uga S, Minami T, Nagata K (1996) Defecation habits of cats and dogs and contamination by Toxocara eggs in public park sandpits. Am. j. trop. med. hyg. 54: 122126.

[67] Lass A, Pietkiewicz H, Modzelewska E, Dumètre A, Szostakowska B, Myjak P (2009) Detection of Toxoplasma gondii oocysts in environmental soil samples using molecular methods. Eur. j. clin. microbiol. Infect. dis. 28: 599-605.

[68] Du F, Feng HL, Nie H, Tu P, Zhang QL, Hu M, Zhou YQ, Zhao JL (2012) Survey on the contamination of Toxoplasma gondii oocysts in the soil of public parks of Wuhan, China. Vet. parasitol. 184: 141-146.

[69] Bobić B, Jevremović I, Marinković J, Šibalić D, Djurković-Djaković O (1998) Risk factors for Toxoplasma infection in a reproductive age female population in the area of Belgrade, Yugoslavia. Eur. j. epidemiol. 14: 605-610.

[70] Kortbeek LM, De Melker HE, Veldhuijzen IK, Conyn-Van Spaendonck MAE (2004) Population-based Toxoplasma seroprevalence study in the Netherlands. Epidemiol. infect. 132: 839-845.

[71] Frenkel JK, Hassanein KL, Hassanein RS, Brown E, Thulliez P, Quintero-Nunez R (1995) Transmission of Toxoplasma gondii in Panama city, Panama: A five-year prospective 
cohort study of children, cats, rodents, birds, and soil. Am. j. trop. med. hyg. 53: 458468.

[72] Lehmann T, Graham DH, Dahl E, Sreekumar C, Launer F, Corn JL, Gamble HR, Dubey JP (2003) Transmission dynamics of Toxoplasma gondii on a pig farm. Infect. genet. evol. 3: 135-141.

[73] Gauss CB, Dubey JP, Vidal D, Cabezon O, Ruiz-Fons F, Vicente J, Marco I, Lavin S, Gortazar C, Almería S (2006) Prevalence of Toxoplasma gondii antibodies in red deer (Cervus elaphus) and other wild ruminants from Spain. Vet. parasitol. 136: 193-200.

[74] Malmsten J, Jakubek EB, Bjorkman C (2011) Prevalence of antibodies against Toxoplasma gondii and Neospora caninum in moose (Alces alces) and roe deer (Capreolus capreolus) in Sweden. Vet. parasitol. 177: 275-280.

[75] Williamson JMW, Williams H (1980) Toxoplasmosis in farmed red deer (Cervus elaphus) in Scotland. Res. vet. sci. 29: 36-40.

[76] Simon A, Chambellant M, Ward BJ, Simard M, Proulx JF, Levesque B, Bigras-Poulin M, Rousseau AN, Ogden NH (2011) Spatio-temporal variations and age effect on Toxoplasma gondii seroprevalence in seals from the Canadian Arctic. Parasitology 138: 17.

[77] Tizard IR, Fish NA, Quinn JP (1976) Some observations on the epidemiology of toxoplasmosis in Canada. J. hyg. Camb. 77: 11-21.

[78] Gotteland C, Aubert A, Gilbert P, Moinet M, Klein F, Villena I, Game Y, Gilot-Fromont E (submitted) Toxoplasma gondii in natural populations of Ungulates in France : prevalence and spatio-temporal variations.

[79] Dumètre A, Dardé ML (2003) How to detect Toxoplasma gondii oocysts in environmental samples? FEMS microbiol. rev. 27: 651-661.

[80] Davies, CM, Altavilla N, Krogh M, Ferguson CM, Deere DA, Ashbolt NJ (2005) Environmental inactivation of Cryptosporidium oocysts in catchment soils. J. appl. microbiol. 98: 308-317.

[81] Langkjær M, Roepstorff A (2008) Survival of Isospora suis oocysts under controlled environmental conditions. Vet. parasitol. 152: 186-193.

[82] Frenkel JK, Ruiz A, Chinchilla M (1975) Soil survival of Toxoplasma oocysts in Kansas and Costa Rica. Am. j. trop. med. hyg. 24: 439-443.

[83] Lélu M, Villena I, Dardé ML, Aubert D, Geers R, Dupuis E, Marnef F, Poulle ML, Gotteland C, Dumètre A, Gilot-Fromont E (2012) Quantitative assessment of the survival of Toxoplasma gondii oocysts in soil. Appl. env. microbiol. doi: 10.1128/AEM.00246-12.

[84] Stenseth NC,Viljugrein H, Jedrejewski W, Mysterud A, Pucek Z (2002) Population dynamics of Clethrionomys glareolus and Apodemus flavicollis : seasonal components of density dependence and density independence. Acta theriol. 47 (Suppl. 1): 39-67.

[85] Tizard R, Harmeson J, Lai CH (1978) The Prevalence of Serum Antibodies to Toxoplasma gondii in Ontario Mammals. Can. j. comp. med. 42: 177-183.

[86] Bobić B, Klun I, Nikolić A, Nikolić A, Vujanić M, Zivković T, Ivović V, DjurkovićDjakovic O (2010) Seasonal variations in human Toxoplasma infection in Serbia. Vector borne zoonotic dis. 10: 465-469. 
[87] Herrmann DC, Pantchev N, Vrhovec MG, Barutzki D, Wilking H, Fröhlich A, Lüder CG, Conraths FJ, Schares G (2010) Atypical Toxoplasma gondii genotypes identified in oocysts shed by cats in Germany. Int. j. parasitol. 40: 285-292.

[88] Klun I, Djurkovic-Djakovic O, Katic-Radivojevic S, Nikolic A (2006) Cross-sectional survey on Toxoplasma gondii infection in cattle, sheep and pigs in Serbia: seroprevalence and risk factors. Vet. parasitol. 135: 121-131.

[89] Panadero R, Painceira A, López C, Vázquez L, Paz A, Díaz P, Dacal V, Cienfuegos S, Fernández G, Lago N, Díez-Baños P, Morrondo P (2010) Seroprevalence of Toxoplasma gondii and Neospora caninum in wild and domestic ruminants sharing pastures in Galicia (Northwest Spain). Res. vet. sci 88: 111-115.

[90] Beral M, Rossi S, Aubert D, Gasqui P, Terrier ME, Klein F, Geers R, Abrial D, GilotFromont E, Richomme C, Hars J, Jourdain E (submitted) Environmental factors associated with the seroprevalence of Toxoplasma gondii in wild boar (Sus scrofa), France.

[91] Richomme C, Afonso E, Tolon V, Ducrot C, Halos L, Alliot A, Perret C, Thomas M, Boireau P, Gilot-Fromont E (2010) Risk factors for Toxoplasma gondii infection in wild boar from the Mediterranean island of Corsica. Epidemiol. infect. 138: 1257-1266.

[92] Langlais M, Lélu M, Avenet C, Gilot-Fromont E (2012) A simplified model system for Toxoplasma gondii spread within a heterogeneous environment. Nonlinear Dynamics, doi: 10.1007/s11071-011-0255-4.

[93] Lopes WDZ, dos Santos TR, dos Santos da Silva R, Rossanese WM, de Souza FA, D'Ark de Faria Rodrigues J, Paranhos de Mendonça R, Soares VE, da Costa AJ (2010) Seroprevalence of and risk factors for Toxoplasma gondii in sheep raised in the Jaboticabal, microregion, São Paulo State, Brazil. Res. vet. sci 161: 324-326.

[94] Mainar RC, de la Cruz C, Asencio A, Dominguez L, Vazquez-Boland IA (1996) Prevalence of agglutination antibodies to Toxolasma gondii in small ruminants of the Madrid region, Spain, and identification of factors influencing seropositivity by multivariate analysis. Vet. res. com. 20: 153-159.

[95] Mateus-Pinilla NE, Hannon B, Weigel M (2002) A computer simulation of the prevention of the transmission of Toxoplasma gondii on swine farms using a feline $T$ gondii vaccine. Prev. vet. med. 55: 17-36.

[96] Kijlstra A, Jongert E (2008) Control of the risk of human toxoplasmosis transmitted by meat. Int. j. parasitol. 38: 1359-1370.

[97] Gilot-Fromont E, Aubert D, Belkilani S, Hermitte P, Gibout O, Geers R, Villena I (2009) Landscape, herd management and within-herd seroprevalence of Toxoplasma gondii in beef cattle herds from Champagne-Ardenne, France. Vet. parasitol. 161: 36-40.

[98] Hill DE, Chirukandoth S, Dubey JP (2005) Biology and epidemiology of Toxoplasma gondii in man and animals. Anim. health res. rev. 6: 41-61.

[99] Cabezón O, García-Bocanegra I, Molina-López R, Marco I, Blanco JM, Höfle U, Margalida A, Bach-Raich E, Darwich L, Echeverría I, Obón E, Hernández M, Lavín S, Dubey JP, Almería S (2011) Seropositivity and risk factors associated with Toxoplasma gondii infection in wild birds from Spain. PloS ONE 6: 1-7. 
[100] Sobrino R, Cabezón O, Millán J, Pabón M, Arnal MC, Luco DF, Gortázar C, Dubey JP, Almería $S$ (2007) Seroprevalence of Toxoplasma gondii antibodies in wild carnivores from Spain. Vet. parasitol. 148: 187-192.

[101] García-Bocanegra I, Dubey JP, Martínez F, Vargas A, Cabezón O, Zorrilla I, Arenas A, Almería S (2010). Factors affecting seroprevalence of Toxoplasma gondii in the endangered Iberian lynx (Lynx pardinus). Vet. parasitol. 167: 36-42.

[102] Degen AA, Kam M, Khokhlova IS, Krasnov BR, Barraclough TG (1998) Average daily metabolic rate of rodents: habitat and dietary comparisons. Funct. ecol. 12: 63-73.

[103] Speakman JR (2005) Body size, energy metabolism and lifespan. J. exp. biol. 208: 17171730.

[104] Ottaviani D, Cairns SC, Oliverio M, Boitani L (2006) Body mass as a predictive variable of homerange size among Italian mammals and birds. J. zool. 269: 317-330.

[105] Ruiz A, Frenkel JK (1980) Intermediate and transport hosts of Toxoplasma gondii in Costa Rica. Am. J. trop. med. hyg. 29: 1161-1166.

[106] Lindsay DS, Phelps KK, Smith SA, Flick G, Sumner SS, Dubey JP (2001) Removal of Toxoplasma gondii oocysts from seawater by Eastern oysters (Crassostrea virginica). J eukariot. microbiol. 48: S197-S198.

[107] Putignani L, Mancinelli L, Del Chierico F, Menichella D, Adlerstein D, Angelici MC, Marangi N, Berrilli F, Caffara M, di Regalbono A (2011) Investigation of Toxoplasma gondii presence in farmed shellfish by nested PCR and real-time PCR fluorescent amplicon generation assay (FLAG). Exp. parasitol 127: 409-417.

[108] Dubey JP (2004) Toxoplasmosis - a waterborne zoonosis. Vet. parasitol. 126: 57-72.

[109] Bollo E, Pregel P, Gennero S, Pizzoni E, Rosati S, Nebbia P, Biolatti B (2003) Health status of a population of nutria (Myocastor coypus) living in a protected area in Italy. Res. vet. sci. 75: 21-25.

[110] Nardoni S, Angelici MC, Mugnaini L, Mancianti F (2011). Prevalence of Toxoplasma gondii infection in Myocastor coypus in a protected Italian wetland. Parasite and Vectors 23: 240-243.

[111] Almeria S, Calvete C, Pages A, Gauss CBL, Dubey, JP (2004). Factors affecting the seroprevalence of Toxoplasma gondii infection in wild rabbits (Oryctolagus cuniculus) from Spain. Vet. parasitol. 123: 265-270.

[112] Gamarra JA, Cabezón O, Pabón M, Arnal MC, Luco DF, Dubey JP, Gortázar C, Almería S (2008) Prevalence of antibodies against Toxoplasma gondii in roe deer from Spain. Vet. parasitol. 153: 152-156.

[113] Germain E, Benhamou S, Poulle ML (2008) Spatio-temporal sharing between the European wildcat, the domestic cat and their hybrids. J. zool. 276: 195-203.

[114] Jokelainen P, Isomursu M, Näreaho A, Oksanen A (2011) Natural Toxoplasma gondii infections in European brown hares and mountain hares in Finland: proportional mortality rate, antibody prevalence, and genetic characterization. J. wildl. dis. 47: 154163.

[115] Jokelainen P, Näreaho A, Knaapi S, Oksanen A, Rikula U, Sukura A (2010) Toxoplasma gondii in wild cervids and sheep in Finland: north-south gradient in seroprevalence. Vet. parasitol. 171: 331-336. 
[116] Sepúlveda MA, Muñoz-Zanzi C, Rosenfeld C, Jara R, Pelican KM, Hill D (2011) Toxoplasma gondii in feral American minks at the Maullín river, Chile. Vet. parasitol. 175: 60-65.

[117] Stieve E, Beckmen K, Kania SA, Widner A, Patton S (2010) Neospora caninum and Toxoplasma gondii antibody prevalence in Alaska wildlife. J. wildl. dis. 46: 348-355.

[118] Vikoren T, Tharaldsen J, Fredriksen B, Handeland K (2004) Prevalence of Toxoplasma gondii antibodies in wild red deer, roe deer, moose, and reindeer from Norway. Vet. parasitol. 120: 159-169.

[119] Zarnke RL, Dubey JP, Kwok OC, Ver Hoef JM (2000) Serologic survey for Toxoplasma gondii in selected wildlife species from Alaska. J. wildl. dis. 36: 219-224.

[120] Miller MA, Miller WA, Conrad PA, James ER, Melli AC, Leutenegger CM, Dabritz HA, Packham AE, Paradies D, Harris M, Ames J, Jessup DA, Worcester K, Grigg ME (2008) Type $\mathrm{X}$ Toxoplasma gondii in a wild mussel and terrestrial carnivores from coastal California: New linkages between terrestrial mammals, runoff and toxoplasmosis of sea otters. Int. j. parasitol. 38: 1319-1328.

[121] Massie GN, Ware MW, Villegas EN, Black MW (2010) Uptake and transmission of Toxoplasma gondii oocysts by migratory, filter-feeding fish. Vet. parasitol. 169: 296-303.

[122] Prestrud KW, Asbakk K, Fuglei E, Mørk T, Stien A, Ropstad E, Tryland M, Gabrielsen GW, Lydersen C, Kovacs KM, Loonen MJ, Sagerup K, Oksanen A (2007) Serosurvey for Toxoplasma gondii in arctic foxes and possible sources of infection in the high Arctic of Svalbard. Vet parasitol. 150: 6-12.

[123] Prestrud KW, Asbakk K, Mørk T, Fuglei E, Tryland M, Su C (2008) Direct highresolution genotyping of Toxoplasma gondii in arctic foxes (Vulpes lagopus) in the remote arctic Svalbard archipelago reveals widespread clonal Type II lineage. Vet parasitol. 158: 121-128.

[124] Maubon D, Ajzenberg D, Brenier-Pinchart MP, Dardé ML, Pelloux H (2008) What are the respective host and parasite contributions to toxoplasmosis? Trends parasitol. 24: 299-303.

[125] Innes EA (1997) Toxoplasmosis: comparative species susceptibility and host immune response. Comp. immunol. microbiol. infect. dis. 20: 131-138.

[126] Shimizu K (1958) Studies on toxoplasmosis I: An outbreak of toxoplasmosis among hares (Lepus timidus ainu) in Sapporo. Jap. j. vet. res. 6: 157-166.

[127] Gustafsson K, Järplid B (1997) Toxoplasma gondii infection in the mountain hare (Lepus timidus) and domestic rabbit (Oryctolagus cuniculus). I. Pathology. J. comp. pathol. 117: 351-360.

[128] Gustafsson K, Wattrang E, Fossum C, Heegaard PMH, Lind P, Uggla A (1997) Toxoplasma gondii infection in the mountain hare (Lepus timidus) and domestic rabbit (Oryctolagus cuniculus). II. Early immune reactions. J. comp. pathol. 117: 361-369.

[129] Sedlak K, Literak I, Faldyna M, Toman M, Benak J (2000) Fatal toxoplasmosis in brown hares (Lepus europaeus): Possible reasons of their high susceptibility to the infection. Vet. parasitol. 93: 13-28. 
[130] Kenny DE, Lappin MR, Knightly F, Baler J, Brewer M, Getzy DM (2002) Toxoplasmosis in Pallas' cats (Otocolobus felis manul) at the Denver Zoological Gardens. J. zoo wildl. med. 33: 131-138.

[131] Basso W, Edelhofer R, Zenker W, Möstl K, Kübber-Heiss A, Prosl H (2005) Toxoplasmosis in Pallas' cats (Otocolobus manul) raised in captivity. Parasitology 130: 293-299. Erratum in: Parasitology 130: 586.

[132] Brown M, Lappin MR, Brown JL, Munkhtsog B, Swanson WF (2005) Exploring the ecologic basis for extreme susceptibility of Pallas' cats (Otocolobus manul) to fatal toxoplasmosis. J wildl dis. 41: 691-700.

[133] Convention on international trade in threatened species (2001) Checklist of CITES species Convention on International Trade in Threatened Species, Geneva, Switzerland, http://www.felineconservation.org/feline_species/pallas_cat.htm.

[134] Ajzenberg D, Bañuls AL, Tibayrenc M, Dardé ML (2002) Microsatellite analysis of Toxoplasma gondii shows considerable polymorphism structured into two main clonal groups. Int j. parasitol. 32:27-38.

[135] Su C, Khan A, Zhou P, Majumdar D, Ajzenberg D, Dardé ML, Xing-Quan Zhu XQ, Ajioka JW, Rosenthal BM, Dubey JP, Sibley LD (2012) Globally diverse Toxoplasma gondii isolates comprise six major clades originating from a small number of distinct ancestral lineages. Proc. nat. acad. sci. doi: 10.1073/pnas.1203190109.

[136] Ajzenberg D, Collinet F, Mercier A, Vignoles P, Dardé ML (2010) Genotyping of Toxoplasma gondii isolates with 15 microsatellite markers in a single multiplex PCR assay. J. clin. microbiol. 48: 4641-4645.

[137] De Craeye S, Speybroeck N, Ajzenberg D, Dardé ML, Collinet F, Tavernier P, Van Gucht S, Dorny P, Dierick K (2010) Toxoplasma gondii and Neospora caninum in wildlife: common parasites in Belgian foxes and Cervidae? Vet. parasitol. 178: 64-69.

[138] Richomme C, Aubert D, Gilot-Fromont E, Ajzenberg D, Mercier A, Ducrot C, Ferté H, Delorme D, Villena I (2009) Genetic characterization of Toxoplasma gondii from wild boar (Sus scrofa) in France. Vet. parasitol. 164: 296-300.

[139] Aubert D, Ajzenberg D, Richomme C, Gilot-Fromont E, Terrier ME, de Gevigney C, Game Y, Maillard D, Gibert P, Dardé ML, Villena I (2010) Molecular and biological characteristics of Toxoplasma gondii isolates from wildlife in France. Vet. parasitol. 171: 346-349.

[140] Aubert D, Terrier ME, Dumètre A, Barrat J, Villena I (2008) Prevalence of Toxoplasma gondii in raptors from France. J. wildl. dis. 44: 172-173.

[141] Jokelainen P, Isomursu M, Nareaho A, Oksanen A (2010) Toxoplasma gondii killing European brown hares and mountain hares in Finland: Proportional mortality rate, seroprevalence, and genetic characterization. 9th Biennial Conference of the European Wildlife, Association, Vlieland, The Netherlands, 13 to 16 September 2010.

[142] Su C, Zhang X, Dubey JP (2006) Genotyping of Toxoplasma gondii by multilocus PCRRFLP markers: a high resolution and simple method for identification of parasites. Int. j. parasitol. 36: 841-848. 
[143] Aspinall TV, Marlee D, Hyde JE, Sims PF (2002) Prevalence of Toxoplasma gondii in commercial meat products as monitored by polymerase chain reaction - food for thought? Int. j. parasitol. 32: 1193-1199.

[144] Dumètre A, Ajzenberg D, Rozette L, Mercier A, Dardé ML (2006) Toxoplasma gondii infection in sheep from Haute-Vienne, France: seroprevalence and isolate genotyping by microsatellite analysis. Vet. parasitol. 142: 376-379.

[145] Halos L, Thébault A, Aubert D, Thomas M, Perret C, Geers R, Alliot A, Escotte-Binet S, Ajzenberg D, Dardé ML, Durand B, Boireau P, Villena I (2010) An innovative survey underlining the significant level of contamination by Toxoplasma gondii of ovine meat consumed in France. Int. j. parasitol. 40: 193-200.

[146] Owen MR, Trees AJ (1999) Genotyping of Toxoplasma gondii associated with abortion in sheep. J parasitol. 85: 382-384.

[147] Jungersen G, Jensen L, Rask MR, Lind P (2002) Non-lethal infection parameters in mice separate sheep Type II Toxoplasma gondii isolates by virulence. Comp. immunol. microbiol. infect. dis. 25: 187-195.

[148] Dubey JP, Velmurugan GV, Rajendran C, Yabsley MJ, Thomas NJ, Beckmen KB, Sinnett D, Ruid D, Hart J, Fair PA, McFee WE, Shearn-Bochsler V, Kwok OC, Ferreira LR, Choudhary S, Faria EB, Zhou H, Felix TA, Su C (2011) Genetic characterisation of Toxoplasma gondii in wildlife from North America revealed widespread and high prevalence of the fourth clonal type. Int. j. parasitol. 41: 1139-1147.

[149] Wendte JM, Gibson AK, Grigg ME (2011) Population genetics of Toxoplasma gondii: new perspectives from parasite genotypes in wildlife. Vet. parasitol. 182: 96-111.

[150] Smith DD, Frenkel JK (1995) Prevalence of antibodies to Toxoplasma gondii in wild mammals of Missouri and east central Kansas: biologic and ecologic considerations of transmission. J. wildl. dis. 31: 15-21.

[151] de Thoisy B, Demar M, Aznar C, Carme B (2003) Ecologic correlates of Toxoplasma gondii exposure in free-ranging neotropical mammals. J. wildl. dis. 39: 456-459.

[152] Santos PS, Albuquerque GR, da Silva VM, Martin AR, Marvulo MF, Souza SL, Ragozo AM, Nascimento CC, Gennari SM, Dubey JP, Silva JC. (2011) Seroprevalence of Toxoplasma gondii in free-living Amazon River dolphins (Inia geoffrensis) from central Amazon, Brazil. Vet. parasitol. 29: 171-173.

[153] Sobral CA, Amendoeira MR, Teva A, Patel BN, Klein CH (2005) Seroprevalence of infection with Toxoplasma gondii in indigenous Brazilian populations. Am. j. trop. med. hyg. 72: 37-41.

[154] Berengo A, Pampiglione S, De Lalla F (1974) Serological studies on toxoplasmosis in some groups of Babiga Pygmies in Central Africa. Riv. parassitol. 35: 81-86.

[155] Johnson WE, Eizirik E, Pecon-Slattery J, Murphy WJ, Antunes A, Teeling E, O'Brien SJ (2006) The late Miocene radiation of modern Felidae: a genetic assessment. Science 311: 73-77.

[156] IUCN SSC Group CS (1996) Cat Website. Available: http://lynx.uio.no/lynx/catsgportal/cat-website/20_cat-website/home/index_en.htm. 02.04.2012. 
[157] Elmore SA, Jones JL, Conrad PA, Patton S, Lindsay DS, Dubey JP (2010) Toxoplasma gondii: epidemiology, feline clinical aspects, and prevention. Trends parasitol. 26: 190196.

[158] Ullmann LS, da Silva RC, de Moraes W, Cubas ZS, dos Santos LC, Hoffmann JL, Moreira N, Guimaraes AM, Montaño P, Langoni H, Biondo AW (2010) Serological survey of Toxoplasma gondii in captive Neotropical felids from Southern Brazil. Vet. parasitol. 172: 144-146.

[159] Bevins SN, Carver S, Boydston EE, Lyren LM, Alldredge M, Logan KA, Riley SP, Fisher RN, Vickers TW, Boyce W, Salman M, Lappin MR, Crooks KR, VandeWoude S (2012) Three pathogens in sympatric populations of pumas, bobcats, and domestic cats: implications for infectious disease transmission. PLoS ONE 7: e31403.

[160] Boothroyd JC (2009) Expansion of host range as a driving force in the evolution of Toxoplasma. Mem. inst. Oswaldo Cruz 104: 179-184.

[161] Carme B, Demar-Pierre M (2006) [Toxoplasmosis in French Guiana. Atypical neotropical features of a cosmopolitan parasitosis]. Med. trop. (Mars) 66: 495-503.

[162] Carme B, Demar M, Ajzenberg D, Dardé ML (2009) Severe acquired toxoplasmosis caused by wild cycle of Toxoplasma gondii, French Guiana. Emerg. infect. dis. 15: 656658.

[163] Dardé ML, Villena I, Pinon JM, Beguinot I (1998) Severe toxoplasmosis caused by a Toxoplasma gondii strain with a new isoenzyme type acquired in French Guyana. J. clin. microbiol. 36: 324.

[164] Ajzenberg D, Banuls AL, Su C, Dumetre A, Demar M, Carme B, Dardé ML (2004) Genetic diversity, clonality and sexuality in Toxoplasma gondii. Int. j. parasitol. 34: 11851196.

[165] Mercier A, Ajzenberg D, Devillard S, Demar MP, de Thoisy B, Bonnabau H, Collinet F, Boukhari R, Blanchet D, Simon S, Carme B, Dardé ML (2011) Human impact on genetic diversity of Toxoplasma gondii: Example of the anthropized environment from French Guiana. Infect. genet. evol. 11: 1378-1387.

[166] Elbez-Rubinstein A, Ajzenberg D, Dardé ML, Cohen R, Dumètre A, Yera H, Gondon E, Janaud JC, Thulliez P (2009) Congenital toxoplasmosis and reinfection during pregnancy: case report, strain characterization, experimental model of reinfection, and review. J. infect. dis. 199: 280-285.

[167] Grigg ME, Bonnefoy S, Hehl AB, Suzuki Y, Boothroyd JC (2001) Success and virulence in Toxoplasma as the result of sexual recombination between two distinct ancestries. Science 294: 161-165.

[168] Su C, Evans D, Cole RH, Kissinger JC, Ajioka JW, Sibley LD (2003) Recent expansion of Toxoplasma through enhanced oral transmission. Science 299: 414-416.

[169] Mercier A, Devillard S, Ngoubangoye B, Bonnabau H, Bañuls AL, Durand P, Salle B, Ajzenberg D, Dardé ML (2010) Additional Haplogroups of Toxoplasma gondii out of Africa: Population structure and mouse-virulence of strains from Gabon. PLoS negl. trop. dis 4: e876.

[170] Ajzenberg D, Yera H, Marty P, Paris L, Dalle F, Menotti J, Aubert D, Franck J, Bessieres $\mathrm{MH}$, Quinio D, Pelloux H, Delhaes L, Desbois N, Thulliez P, Robert-Gangneux F, 
Kauffmann-Lacroix C, Pujol S, Rabodonirina M, Bougnoux ME, Cuisenier B, Duhamel C, Duong TH, Filisetti D, Flori P, Gay-Andrieu F, Pratlong F, Nevez G, Totet A, Carme B, Bonnabau H, Dardé ML, Villena I (2009) Genotype of 88 Toxoplasma gondii isolates associated with toxoplasmosis in immunocompromised patients and correlation with clinical findings. J. infect. dis. 199: 1155-1167.

[171] Lehmann T, Marcet PL, Graham DH, Dahl ER, Dubey JP (2006) Globalization and the population structure of Toxoplasma gondii. Proc. natl. acad. sci. U S A 103: 11423-11428.

[172] Dubey JP, Quirk T, Pitt JA, Sundar N, Velmurugan GV, Kwok OC, Leclair D, Hill R, Su C (2008) Isolation and genetic characterization of Toxoplasma gondii from raccoons (Procyon lotor), cats (Felis domesticus), striped skunk (Mephitis mephitis), black bear (Ursus americanus), and cougar (Puma concolor). J. parasitol. 94: 42-45.

[173] Kapperud G, Jenum PA, Stray-Pedersen B, Melby KK, Eskild A, Eng J (1996) Risk factors for Toxoplasma gondii infection in pregnancy. Results of a prospective casecontrol study in Norway. Am. j. epidemiol. 144: 405-412.

[174] Bowie WR, King AS, Werker DH, IsaacRenton JL, Bell A, Eng SB, Marion SA (1997) Outbreak of toxoplasmosis associated with municipal drinking water. Lancet 350: 173177.

[175] Aubert D, Villena I (2009) Detection of Toxoplasma gondii oocysts in water: proposition of a strategy and evaluation in Champagne-Ardenne Region, France. Memorias Do Instituto Oswaldo Cruz 104: 290-295.

[176] Baril L, Ancelle T, Goulet V, Thulliez P, Tirard-Fleury V, Carme B (1999) Risk factors for Toxoplasma infection in pregnancy: A case-control study in France. Scand. j. infect. dis. 31: 305-309.

[177] AFSSA (2005) Toxoplasmose : état des connaissances et évaluation du risque lié à l'alimentation Rapport du groupe de travail « Toxoplasma gondii » de l'Afssa. http://www.anses.fr/cgi-bin/countdocs.cgi?Documents/MIC-Ra-Toxoplasmose.pdf.

[178] Opsteegh M, Prickaerts S, Frankena K, Evers EG (2011) A quantitative microbial risk assessment for meatborne Toxoplasma gondii infection in The Netherlands. Int. j. food microbiol. 150: 103-114.

[179] Kijlstra A, Meerburg BG, Mul MF (2004) Animal-friendly production systems may cause re-emergence of Toxoplasma gondii. Njas-Wageningen Journal of Life Sciences 52: 119-132.

[180] van der Giessen J, Fonville M, Bouwknegt M, Langelaar M, Vollema A (2007) Seroprevalence of Trichinella spiralis and Toxoplasma gondii in pigs from different housing systems in The Netherlands. Vet. parasitol. 148: 371-374.

[181] Meerburg BG, Van Riel JW, Cornelissen JB, Kijlstra A, Mul MF (2006) Cats and goat whey associated with Toxoplasma gondii infection in pigs. Vector-Borne and Zoonotic Diseases 6: 266-274.

[182] Kijlstra A, Meerburg B, Cornelissen J, De Craeye S, Vereijken P, Jongert E (2008) The role of rodents and shrews in the transmission of Toxoplasma gondii to pigs. Vet. parasitol. 156: 183-190. 
[183] Dubey JP, Hill DE, Rozeboom DW, Rajendran C, Choudhary S, Ferreira LR, Kwok OC, Su C (2012) High prevalence and genotypes of Toxoplasma gondii isolated from organic pigs in northern USA. Vet parasitol. in press.

[184] Kijlstra A, Jongert E (2009) Toxoplasma-safe meat: close to reality? Trends parasitol. 25: 18-22.

[185] Lélu M, Gilot-Fromont E, Aubert D, Afonso E, Dupuis E, Gotteland C, Dardé ML, Marnef F, Poulle ML, Richaume-Jolion A, Villena I (2011) Development of a sensitive method for Toxoplasma gondii oocysts extraction in soil samples. Vet. parasitol. 183: 5967.

[186] Villena I, Aubert D, Gomis P, Ferté H, Inglard JC, Denis-Bisiaux H, Dondon JM, Pisano E, Ortis N, Pinon JM (2004) Evaluation of a strategy for Toxoplasma gondii oocyst detection in water. Appl. environ. microbiol. 70: 4035-4039.

[187] Kourenti C, Karanis P (2006) Evaluation and applicability of a purification method coupled with nested PCR for the detection of Toxoplasma oocysts in water. Lett. appl. microbiol. 43: 475-481.

[188] Borchardt MA, Spencer SK, Bertz PD, Ware MW, Dubey JP, Alan Lindquist HD (2009) Concentrating Toxoplasma gondii and Cyclospora cayetanensis from surface water and drinking water by continuous separation channel centrifugation. J. appl. microbiol. 107: 1089-1097.

[189] Du F, Zhanga Q, Yu Q, Hu M, Zhou Y, Zhao J (2012) Soil contamination of Toxoplasma gondii oocysts in pig farms in central China. Vet. parasitol. doi:10.1016/j.vetpar.2011.12.036.

[190] Hill D, Coss C, Dubey JP, Wroblewski K, Sautter M, Hosten T, Muñoz-Zanzi C, Mui E, Withers S, Boyer K, Hermes G, Coyne J, Jagdis F, Burnett A, McLeod P, Morton H, Robinson D, McLeod R (2011) Identification of a sporozoite-specific antigen from Toxoplasma gondii. J. parasitol. 97: 328-37.

[191] Muñoz-Zanzi CA, Fry, P Lesina B, Hill D (2010) Toxoplasma gondii Oocyst-specific Antibodies and Source of Infection. Emerg. infect. dis 16: 1591-1596.

[192] Muñoz-Zanzi C, Tamayo R, Balboa J, Hill D (2012) Detection of oocyst-associated toxoplasmosis in swine from Southern Chile. Zoonoses pub. health. doi: 10.1111/j.18632378.2012.01471.x.

[193] Boyer K, Hill D, Mui E, Wroblewski K, Karrison T, Dubey JP, Sautter M, Noble AG, Withers S, Swisher C, Heydemann P, Hosten T, Babiarz J, Lee D, Meier P, McLeod R (2011) Toxoplasmosis Study Group. Unrecognized ingestion of Toxoplasma gondii oocysts leads to congenital toxoplasmosis and causes epidemics in North America. Clin. infect. dis. 53: 1081-1089. 